The Rise of the Islamic State: How the Nouri al-Maliki government set the conditions for the resurgence of Islamic extremism in Iraq

\author{
Arthur Vance Morgan, V \\ Charlottesville, Virginia
}

\begin{abstract}
A.A. Arabic, Defense Language Institute, 2013
M.A. Business and Organizational Security Management, Webster University, 2012 B.S. Wildlife Science, Virginia Tech, 2004
\end{abstract}

A Thesis presented to the Graduate Faculty of the University of Virginia in Candidacy for the Degree of Master of Arts in Middle Eastern and South Asian Studies

Department of Middle Eastern and South Asian Languages and Cultures

\author{
University of Virginia
}

December, 2016 
In 2014 much of the world was taken aback by the seemingly over-night appearance of the Islamic State of Iraq and the Levant, which captured vast swaths of territory in Syria and Iraq within a few short months. The chaos created by the American withdrawal from Iraq and the Syrian civil war provided a small group of radical Sunni Islamists with poorly defended territory and fertile recruiting grounds. When the group came out of the shadows and captured city after city in northern and western Iraq, it displayed remarkable strength and speed, and a surprising ability to capture and hold territory. Their unprecedented battlefield successes proved that Iraq was still far from being the united and democratic country that the US government hoped to build in the Middle East. Despite international shock at the group's success, its occupation of portions of northern and western Iraq should have hardly been a surprise. The Iraqi government's pro-Shia policies left the nation's Sunni leaders in a precarious position in which they were forced to choose between an untrustworthy government and Islamic extremists.

Though many narratives have emerged since ISIS first grabbed international headlines, two interconnected narratives dominate the literature. The first argues that repeated failures by subsequent US administrations are primarily responsible for the present situation in Iraq. In a July 2014 interview, Ryan Crocker, who served as the US ambassador to Iraq from 2007 to 2009, stated that the United States "disengaged not only militarily at the end of 2011, we disengaged politically." ${ }^{1}$ Due to the deep divisions between the Sunni Arabs, Shia Arabs and Kurds, the US had become the key intermediary between the groups. Crocker adds that when the US left Iraq, the three groups returned to zero-sum thinking where no group was willing to compromise. ${ }^{2}$ During a USA Today interview in October 2014, former CIA director and

1 Ryan Crocker, "Losing Iraq," transcript by Sarah Childress, Frontline, PBS, July 10, 2014.

2 Ibid. 
Secretary of Defense Leon Panetta ${ }^{3}$ argued that with greater effort the US could have reached a deal to keep US forces in Iraq after 2011. ${ }^{4}$ The failure to do so "created a vacuum in terms of the ability of that country to better protect itself, and it's out of that vacuum that ISIS began to breed." Panetta criticized President Obama's lack of decisiveness in supporting moderate Syrian rebels early in the conflict, as the failure to do so allowed the Syrian civil war to continue and extremism to spread. ${ }^{5}$ Reidar Visser ${ }^{6}$ acknowledges Maliki's many faults, but repeatedly points to American missteps as the primary cause of violent sectarianism in Iraq today. He views Maliki's government as the result of a US “approach that stressed proportional sectarian representation rather than national unity and moderate Islamism." ${ }^{7}$ In an opinion piece for the Washington Post, Ali Khedery, ${ }^{8}$ who served as a special assistant to US ambassadors in Iraq, lays out a detailed description of Maliki's transformation from a nationalist in 2006 to a budding tyrant and Shiite Islamist in 2010. Though he recognizes Maliki's faults, Khedery places significant blame on the Obama administration for its unwavering support for Maliki despite his consolidation of power and alienation of the Sunni community. ${ }^{9}$ Whether blaming America's initial missteps in Iraq, its support for a divisive leader, or its failure to remain politically and militarily engaged after 2011, this narrative views US failures as the primary cause of the chaos Iraq is experiencing today.

\footnotetext{
3 Leon Panetta served as the Director of Central Intelligence Agency from 2009 to 2011 and as Secretary of Defense from 2011 to 2013 under the Obama administration.

4 Susan Page, "Panetta: '30-year war' and a leadership test for Obama," USA Today, October 6, 2014, accessed November 11, 2016, http://www.usatoday.com/story/news/politics/2014 /10/06/leon-panetta-memoir-worthyfights $16737615 /$.

5 Ibid.

6 Reidar Visser is a senior research fellow at the Norwegian Institute of International Affairs.

7 Reidar Visser, “An Unstable, Divided Land,” New York Times, December 15, 2011, accessed November 7, 2016, http://www.nytimes.com/2011/12/16/opinion/an-unstable-divided-land.html?_r=1.

8 Ali Khedey is a native Arabic speaker who served in Iraq from 2003-2009 as a special assistant to US ambassadors and subsequently as a senior advisor to the head of US Central Command.

9 Ali Khedery, "Why we stuck with Maliki - and lost Iraq," Washington Post, July 3, 2014, accessed November 7 , 2016, https://www.washingtonpost.com/opinions/why-we-stuck-with-maliki--and-lost-iraq/2014/07/03/0dd6a8a4-

f7ec-11e3-a606-946fd632f9f1_story.html.
} 
The second narrative acknowledges US mistakes, but views Nouri al-Maliki's sectarian policies as the primary cause of the resurgence of extremism. The 2003 US-led invasion and subsequent occupation of Iraq dramatically altered the balance of power within the country. As the insurgency took hold, Iraq became a magnet for young Muslim men inspired to fight for myriad reasons. As the violence intensified, sectarian tensions boiled to the surface in the most violent of fashions. By the end of the US "surge" of troops in 2008, one of the most violent groups, al Qaeda in Iraq (AQI), was all but defeated and its leaders disappeared into hiding.

Recently elected prime minister, Nouri al-Maliki, who campaigned on a platform of uniting Iraq, had a unique opportunity to bring together Iraq's disparate sectarian groups in order to create a unified government. Rather than fulfill those promises, the prime minister's decisions and policy making became increasingly sectarian, and at times authoritarian. He forfeited the opportunity to unite the people of Iraq in favor of securing his own position as leader of the Shi'ite majority. Retired General David Petraeus ${ }^{10}$ stated that "Prime Minister Nouri Maliki, whose highly sectarian actions....alienated the Sunni-Arab population and created fertile fields for the planting of the seeds of extremism which the Islamic State then used."11 The polarizing effect of his government opened the door to the extremists of the Islamic State to gain local Sunni support and seize territory throughout northern and western Iraq. Middle East scholar Toby Dodge 12 argues that the "failure to build a sustainable and inclusive political system after the regime change in 2003 and the authoritarianism of Maliki explains the rise of ISIS."13

10 David Petraeus served as the Multinational Force - Iraq commander from 2007-2008 and is attributed with devising the "surge" strategy that was a turning point in the Iraq war.

11 David Petraeus, "Tonight on Charlie Rose," Interview by Charlie Rose, Frontline, PBS, September 28, 2016, https://charlierose.com/videos/28902.

12 Toby Dodge is the Director of the London School of Economics Middle East Centre.

13 Toby Dodge, "Iraq doesn't have to fall apart. It can be reformed," Guardian, June 13, 2014, accessed November 11, 2016, https://www.theguardian.com/commentisfree/2014/jun/ 13/iraq-isis-terrible-decisions-2003new-course-state-survive. 
Though former Secretary of Defense Robert Gates partially attributes Maliki's anti-Sunni policies to the lack of US political engagement in Iraq after 2011, he also stated in a June 2016 interview that "Maliki gave the Sunnis in Iraq no reason to resist ISIS." ${ }^{14}$ Even though the US made countless missteps during the occupation and transition, Nouri al-Maliki's actions, which deepened the divides within Iraqi society rather than attempting to unify the people, ultimately precipitated the resurgence of Islamic extremism. This paper argues that the sectarian policies and poor leadership decisions of the Nouri al-Maliki government set the conditions for the resurgence of Sunni Islamic extremism in Iraq and the development of the Islamic State caliphate.

In order to support this thesis, this paper will establish a pattern of decisions and policies that increasingly gave Maliki tighter control of the state while further alienating the Sunni population. His efforts to consolidate power and eliminate his rivals, even when not directed at the Sunni population, served as a constant reminder that the government in Baghdad was deeply corrupt and could not be trusted. Maliki's handling of the government eventually pushed the Sunni Arab population to the breaking point, where all hope for reconciliation was abandoned. That moment in time coincided with the resurgence of Sunni extremist forces across the border in Syria, who exploited Sunni anger and mistrust toward the government in Baghdad. With Sunni - Shia tensions at the boiling point in 2014, ISIS fighters retook the lands from which they had been driven in 2008. This paper will detail the sectarian policies of the government which allowed the new Islamic caliphate to quickly cement its presence in northern and western Iraq.

\footnotetext{
14 Russ Read, "Former SecDef Robert Gates Gives His Two Reasons Why ISIS Exists," Daily Caller, June 29, 2016, accessed November 11, 2016, http://dailycaller.com/2016/06/29/ former-secdef-robert-gates-gives-his-tworeasons-why-isis-exists/.
} 


\section{Sectarianism in Iraq}

Both Sunnis and Shiites have a rich history in the land now known as Iraq. Though the two groups have lived together for centuries through times of peace and conflict, recent history has set these sects on a collision course. Under its League of Nations mandate, Britain installed a Sunni from what is now Saudi Arabia, as the first monarch of Iraq, thus empowering the minority Sunni community. The $20^{\text {th }}$ century witnessed multiple changes of government and a continual cycle of improving and deteriorating relations between Iraq's Sunni and Shia communities, reaching the worst level in recent history under the regime of Saddam Hussein. ${ }^{17}$

Despite being a clear majority, Iraq's Shia population suffered from exceptionally harsh treatment under the regime of Saddam Hussein. Though there is no official census of the Iraqi population to provide accurate demographics, in 2013 the CIA estimated that $97 \%$ of the 31.8 million Iraqis were Muslim, and of that percentage, $60-65 \%$ were Shia and $32-37 \%$ were Sunni. ${ }^{18}$ From the 1970s, there was clear discrimination by the Sunni minority against the Shiite majority. The persecution of Shias worsened significantly during the Iraq-Iran War during the 1980s. Hussein was highly suspicious of the Shia, many of whom had openly supported the Iranian revolution in $1979 .{ }^{19}$ He violently suppressed any Shia resistance and removed from government any Shia whose loyalty was suspect. Though he drove the Shia resistance out of the country, low-intensity resistance continued until Hussein was removed from power in $2003 .{ }^{20}$ The suffering of the Shia majority under Sunni rule helps to explain the Shia efforts to resist Sunni political influence in post-2003 Iraq.

17 Khalil F. Osman, Sectarianism in Iraq: The Making of State and Nation since 1920 (New York: Routledge, 2015), 80.

18 Anthony H. Cordesman and Sam Khazai, Iraq in Crisis, (Lanham, MD: Rowman \& Littlefield, 2014), 140.

19 Ibid.

${ }^{20}$ Ibid. 


\section{The 2003 Iraq War and the Establishment of a New Government}

Even before the tanks of the $3^{\text {rd }}$ Infantry Division crossed the berm from Kuwait into Iraq in March 2003, Iraqis generally had little trust in the US government. The 1991 US-led campaign to drive Iraqi forces from Kuwait destroyed the civilian and military infrastructure throughout much of Iraq. Citizens were left without power by US targeting of the country's electrical plants, and cholera and typhoid epidemics resulted from the destruction of water purification and sewage treatment facilities. ${ }^{21}$ Believing that the US government would fulfill its perceived commitment, thousands of Iraqis answered President Bush's call to topple Hussein in the spring of 1991, only to be crushed when US support never materialized. ${ }^{22}$ After the war, sanctions continued to devastate Iraq, leading to the inability of the government to provide reliable services, including water, electricity, and health care. The agricultural sector was severely damaged, and the economy suffered from hyperinflation. ${ }^{23}$ Many Iraqi soldiers faced unemployment, government workers experienced significant pay cuts, and the once-strong education system quickly deteriorated. ${ }^{24}$ Years of sanctions caused the people to lose hope in the international community, helping to explain the general feelings of mistrust the Iraqi people held toward the US after the 2003 invasion.

The US's handling of the occupation would do little to heal the wounds left by sanctions, as American missteps from the very beginning of the conflict would directly contribute to the violent rise in sectarianism in post-2003 Iraq. From the beginning of the conflict, American planners emphasized "proportional sectarian representation" instead of a unifying national

${ }^{21}$ Fawaz A. Gerges, ISIS: A History (Princeton, NJ: Princeton University Press, 2016), 99.

${ }^{22}$ Ibid.

23 Ibid.

${ }^{24}$ Ibid. 
government coupled with moderate Islamism. ${ }^{25}$ Visser argues that this one failure was more significant than the large occupying force in 2003, the Abu Ghraib torture scandal a year later, or the surge of troops in 2007 in shaping the current state of affairs in Iraq. During the 1990s, American officials viewed a future post-Hussein "Iraq as a federation of Arabs and Kurds." ${ }^{26}$ It was not until 2002 that Bush administration officials proposed that Iraq's new government should proportionally represent the country's ethno-sectarian groups. The implementation of that policy transformed the longstanding Arab-Kurdish divide into a Sunni-Shiite-Kurdish divide. Despite efforts by moderate Shiites to unify the country, Visser argues that the American's focus on the Sunni-Shiite-Kurdish divide only exacerbated sectarian tensions. ${ }^{27}$ By consistently viewing nearly every issue in Iraq through a sectarian lens, the US administration set the stage for sectarian civil war that would decimate the country.

On June 28, 2004, Paul Bremer, head of the Coalition Provisional Authority, established the interim Iraqi government led by Ayad Allawi, a moderate Shia. ${ }^{28}$ Elections for the 275 seats of Iraq's transitional National Assembly were held on January 30, 2005. Islamist and secular Shia parties won 180 seats, while a Sunni boycott of the elections resulted in only 17 seats being won by Sunni parties. ${ }^{29}$ The Sunni boycott, based on the belief that the elections legitimized the US occupation, ${ }^{30}$ created a dangerous sectarian situation, as the National Assembly was tasked with writing Iraq's constitution. ${ }^{31}$ The National Assembly formed a 55-member Committee on the Writing of the Constitution, with membership based on ethnic and religious sects.

\footnotetext{
25 Visser, “An Unstable,” New York Times, December 15, 2001.

26 Ibid.

27 Ibid.

28 Yasir Kuoti, "Exclusion and Violence in Post-2003 Iraq," Journal of International Affairs 69, no. 2 (Spring/Summer 2016): 21, accessed September 19, 2016, EBSCOhost.

29 Ibid.

30 Rory Carroll, "Sunnis admit poll boycott blunder and ask to share power," Guardian, February 14, 2005, accessed October 29, 2016, https:/www.theguardian.com/world/2005/ feb/15/iraq.rorycarroll.

31 Cordesman and Khazai, Iraq in Crisis, 92.
} 
Membership was broken down as follows: 28 Shia Islamists, 14 Kurds, 8 moderate Shiites, 1 Christian, 1 Turkman, and 2 Sunni representatives. An additional 15 Sunnis were later added to the committee after calls for greater representation, but most withdrew in protest after four Sunni members were assassinated shortly after joining the committee. ${ }^{32}$

In October 2005, the constitution was adopted in a popular referendum, with $78.6 \%$ of Iraqis voting in favor. Despite its overwhelming approval at the national level, the vast majority of Sunnis voted against the constitution, with $97 \%$ in Anbar Province and $82 \%$ in Salah ad-Din Province voting in opposition. ${ }^{33}$ Sunnis felt as though they were unfairly denied the right to participate in drafting the constitution, creating resentment towards the new government. ${ }^{34}$ In addition to a general feeling of disenfranchisement, the Sunni population had specific concerns about certain articles of the constitution. Article 112, for example, provides for additional oil and gas profits to be designated for areas that were deprived of them under Saddam Hussein's regime, or in other words, the Shia and Kurdish regions. ${ }^{35}$ The constitution also specifies that the revenues from present oil and gas fields are to be distributed according to population distribution throughout the country, but it leaves open the possibility that new discoveries may be controlled by regional authorities. This represented a serious concern for Sunnis, as Sunni majority areas have little gas or oil resources. ${ }^{36}$ Article 121 presented another Sunni concern, as it provides regional governments the right to establish internal security forces, which affords a legal justification for Shia militias. ${ }^{37}$

32 Kuoti, "Exclusion," 22.

33 Kenneth Katzman, “Iraq: Elections, Government and Constitution,” Congressional Research Service: 4, accessed September 20, 2016, http://fpc.state.gov/documents/organization/ 76838.pdf.

34 Kuoti, "Exclusion," 22.

35 Iraqi Constitution, art. 112.

36 Katzman, "Iraq: Elections," 3.

37 Ibid. 
The Shiite domination of the legislature continued to marginalize Sunnis, as Shia lawmakers were able to pass legislation with little resistance. ${ }^{38}$ The political system also assigned the position of prime minister to the Shiite majority, allowing Shia control over the Office of the Prime Minister and the parliament. ${ }^{39}$ Though much could be credited to their choice to boycott the election, the exclusion of Sunnis from the political process led them to believe that violence was the best means to disrupt the new government, which justified partnering with extremist groups. ${ }^{40}$

\section{The Development of Al Qaeda in Iraq}

The Iraqi government was not the only organization taking shape during this period, as Sunni resistance included increased violence and stronger ties with external extremist organizations such as Al Qaeda. Abu Mosab al-Zarqawi, who formed al Qaeda in Iraq (AQI), created the vision of a pure Sunni caliphate cleansed of all infidels that continues to pervade Islamic State doctrine. ${ }^{41}$ Jordanian by birth, Zarqawi fought in Afghanistan, where he formed Jamaat al-Tawhid wal-Jihad (JTJ) in 2000 in Herat. After the US invasion of Iraq, he established JTJ in Iraq with the goal of forcing US forces (USF) to withdraw, removing the government in Baghdad, targeting Shiite civilians, leaders, and militias, and establishing an Islamic state. ${ }^{42}$ Zarqawi changed the insurgency by the degree of violence his group used, and who it targeted. Relying on takfiri doctrines, or accusing other Muslims of apostasy, Zarqawi focused on sectarian killing more than any other group at the time, attacking "mosques, schools, cafes,

38 Kuoti, "Exclusion," 24.

39 Ibid., 25.

40 Ibid., 20.

41 Anthony N. Celso, “Zarqawi’s Legacy: Al Qaeda’s ISIS 'Renegade,”” Mediterranean Quarterly 26, no. 2 (June 2015): 21, Duke University Press Journals Online.

42 Wayne F. Lesperance, "The Rise of the Islamic State (IS)," in The New Islamic State: Ideology, Religion and Violent Extremism in the $21^{\text {st }}$ Century, edited by Jack Covarrubias, Tom Lansford and Robert J. Pauly, Jr. (New York: Ashgate Publishing, 2016), 17. 
and markets in Shiite" communities. ${ }^{43}$ He used these sectarian attacks to gain support within more radical elements of the Sunni community, which helped his recruiting efforts and provided safe haven for his organization. ${ }^{44}$

In October 2004, JTJ joined al Qaeda to form AQI, but the relationship with al Qaeda central was strained by the degree of Zarqawi's violence. The mass killings of civilians and targeting of Shiite mosques and festivals angered most Muslims, costing AQI legitimacy and support. In a 2005 letter, Al Qaeda deputy Ayman al Zawahiri rebuked AQI's tactics of targeting "civilians, churches, and Shia," and encouraged Zarqawi to focus his attacks on US forces and Iraqi security forces. ${ }^{45}$ Zarqawi displayed little concern for the opinions of al Qaeda central, though by early 2006 he recognized that AQI was struggling. Many Sunnis were disturbed by the brutality of his attacks, and Sunni leaders increasingly expressed concern about the foreign leadership of AQI. ${ }^{46}$ In addition to being an insurgent leader, Zarqawi had taken on a spiritual role as well, applying sharia law in the areas under AQI control. The forced "veiling of women, execution of apostates, and beheadings for criminals" caused general discontent amongst the Sunni population, at times resulting in the deaths of local leaders who disagreed with his methods. ${ }^{47}$ Needing to put an Iraqi face on his organization, Zarqawi incorporated six Iraqi Islamist groups into AQI, renaming it the Islamic State of Iraq (ISI) in early $2006 .{ }^{48}$ Zarqawi was killed in a US airstrike that June, and his replacement, Abu Umar al Baghdadi, succeeded him and maintained his strategy of mass killings of Shia. ${ }^{49}$

43 Lesperance, “The Rise," 18.

44 Ibid.

45 Celso, "Zarqawi's Legacy," 25.

46 Lesperance, "The Rise," 19.

47 Ibid.

48 Celso, "Zarqawi's Legacy," 25.

49 Ibid. 


\section{Nouri al Maliki}

In early 2006, while Zarqawi was fighting to convert Iraq into an Islamic state through violence and chaos, a little-known politician named Nouri al Maliki was appointed to lead the fledgling Iraqi government. Maliki grew up in the small village of Janaga along the Euphrates River in central Iraq. Throughout his childhood he heard stories of his grandfather, Mohammed Abu Mahesin, who wrote revolutionary poetry and led his tribe in the 1920 revolt against the British. ${ }^{50}$ Though his father was a strong Arab nationalist, Maliki witnessed the failures of nationalism in the 1967 war, and turned to the Islamic Dawa party while studying at Baghdad University in the 1960s. ${ }^{51}$ He served briefly in the army after college, then worked in accounting in a town near his home. There he worked in the shadows spreading the Dawa message of resistance. By the late 1970s Hussein's persecution of the Dawa party became more heavyhanded, and in 1979 Maliki was arrested. ${ }^{52}$ He was released by a judge who was later executed by the Hussein regime, and immediately fled the country. On the day that he left, in October 1979, security forces came to Maliki's office looking for him, but that morning he had left the village in route to Damascus. ${ }^{53}$ The regime took his family's land and executed at least 67 of his relatives over the next ten years. In April 1980, the regime executed Ayatollah Mohammed Baqr Sadr, the spiritual leader of the Dawa movement, increasing the sectarian division within Iraqi society. ${ }^{54}$ The brutal treatment of his family and party members created a spirit of vengeance in Maliki and his Dawa contemporaries. ${ }^{55}$

\footnotetext{
${ }^{50}$ Ned Parker and Raheem Salman, "Notes from the Underground: The Rise of Nouri al-Maliki and the New Islamists," World Policy Journal 30, no. 1 (Spring 2013): 66, accessed August 16, 2016, Duke University Press Journals Online.

51 Ibid.

${ }^{52}$ Ibid., 66-67.

${ }^{53}$ Ibid.

${ }^{54}$ Ibid., 67.

55 Ibid.
} 
In Syria, Maliki helped to establish guerrilla cells in Iraq and to smuggle weapons and propaganda into Iraq. In fateful foreshadowing, Dawa conducted the first modern suicide bombing in the region in 1981, hitting the Iraqi embassy in Beirut with a car bomb. ${ }^{56}$ Maliki proved himself to be a strong leader in Syria, and in 1981 the party leadership sent him to Iran to help run a military training camp. ${ }^{57}$ Despite an initial fascination and respect for the Iranian revolution and Ayatollah Khomeini, life in Iran was not what Maliki expected. The Iranians made unsuccessful attempts to co-opt Dawa, but its members had no intention of being subjugated by the Iranians. ${ }^{58}$ As Dawa resentment grew, the Iranians decided to form a competing movement, the Hakims. The group was named after an Iraqi clergyman, and its militia, the Badr Brigade, would later fight in post-2003 Iraq. ${ }^{59}$ Dawa came under increased hostility from the Iranians, and Maliki developed bitter resentment towards them. ${ }^{60}$

While the 1980s shaped his view of Iran, the early 1990s left him with a distrustful view of the United States. Maliki felt betrayed when the Americans encouraged an uprising against the Hussein regime in 1991, only to let tens of thousands of people be slaughtered by Hussein's forces. After the rebellion had been suppressed, the Dawa party sent Maliki to Saudi Arabia to visit the thousands of Shiites who had escaped. ${ }^{61}$ In his view, the Saudi government treated them with suspicion and hostility, confining them in refugee camps in the desert. ${ }^{62}$ Witnessing the poor treatment of his Shia brethren by another Sunni power likely confirmed Maliki's deepseated suspicions of Sunnis.

\footnotetext{
56 Parker and Salman, "Notes," 67.

57 Ibid.

58 Ibid., 68.

59 Ibid.

${ }^{60}$ Ibid.

${ }^{61}$ Ibid., 69.

${ }^{62}$ Ibid.
} 
While prominent Iraqi exiles were returning with large entourages, Maliki returned quietly from Syria in 2003 in a taxi. He immediately set up a Dawa party office and held a funeral for fellow Dawa members killed by the Hussein regime. He visited his village only to find it in ruins, reminding him of the permanent mark the Baathists had left on him. ${ }^{63}$ It was now his turn to leave a mark by transforming the Iraqi government.

The December 2005 parliamentary elections brought in a new Council of Representatives with a five-year term of office. ${ }^{64}$ Though the Shiite and Kurdish parties combined to hold 181 of the 275 seats, and were thus able to continue their ruling coalition, Sunni parties made significant gains. ${ }^{65}$ The ruling coalition consisted of disparate groups who subsequently entered into a months-long standoff over who to select as the next Prime Minister. ${ }^{66}$ Maliki was selected as a compromise because party leaders did not consider him a threat, and in April 2006 Maliki assumed the role that would propel him to the forefront of national politics. ${ }^{67}$ Their assessment was correct, Maliki did not have a base of support, a militia, or the ability to control members of the other political parties. ${ }^{68}$ Despite the disadvantages he faced, Maliki was quick to gather loyal followers from within his family and the Dawa party and place them in key positions throughout the government, giving him direct access to the people who were executing government policy on a daily basis. ${ }^{69}$ By late 2008 , the man originally seen as weak was being labeled a "strongman" by the international media. ${ }^{70}$

\footnotetext{
63 Parker and Salman, "Notes," 70.

64 Cordesman and Khazai, Iraq in Crisis, 92.

65 Katzman, "Iraq: Elections," 4.

66 Sam Parker, “The New Nouri al-Maliki,” Foreign Policy, July 21, 2009, accessed September 7, 2016, http://foreignpolicy.com/2009/07/23/the-new-nuri-al-maliki/.

67 Katzman, "Iraq: Elections," 4.

68 Parker, "New," Foreign Policy, July 21, 2009.

69 Tody Dodge, "State and society in Iraq ten years after regime change: the rise of a new authoritarianism," International Affairs 89, no. 2 (March 2013): 245, Wiley Online Library.

70 Parker, "New," Foreign Policy, July 21, 2009.
} 


\section{The "Surge" and the Defeat of AQI}

By late-2006 relations between Iraqi's Sunni leaders and ISI, known as AQI until early 2006, had deteriorated sharply. ISI appointed local emirs that usurped authority from tribal leaders. $^{71}$ They took control of smuggling routes used by the tribes, imposed strict sharia law, and launched an assassination campaign against tribal leaders. ${ }^{72}$ ISI leaders even tried to forcibly marry local women to create tribal ties to the organization. ${ }^{73}$ Sunni leaders began to understand that ISI sought to take control of their land and kill their people, rather than liberate them from the US-backed Shia government. ${ }^{74}$ They knew that the Americans, who did not seek to change local customs, would eventually leave Iraq. ISI, on the other hand, never intended to leave, and would control their people with sharia law and supplant the sheikhs' authority. ${ }^{75}$

A tribal revolt against the extremist infiltrators was precisely what was needed to turn the tide in the insurgency. In September 2006, Ramadi tribes formed the al Anbar Salvation Council, which worked in cooperation with US forces. ${ }^{76}$ In October, other tribes joined the movement and established the Majalis al-Sahwa, or the Awakening Councils, which included Sunni fighters known as Concerned Local Citizens or Sons of Iraq (SOI). ${ }^{77}$ Through the remainder of 2006 and 2007, the Awakening movement spread across the Sunni-dominated areas of Iraq, and by early 2008 membership reached around $80,000 .{ }^{78}$ Critical to the movement's success was the level of US support it received. US financing provided arms to the SOI, as well as a monthly individual stipend of $\$ 300$ a month. The Sons of Iraq manned checkpoints,

${ }^{71}$ Gerges, ISIS, 100.

72 Celso, "Zarqawi's Legacy," 26.

${ }^{73}$ Mark Wilbanks and Efraim Karsh, "How the 'Sons of Iraq' Stabilized Iraq," Middle East Quarterly 17, no. 4 (Fall 2010): 59, accessed September 12, 2016, EBSCOhost.

74 Gerges, ISIS, 100.

75 Wilbanks and Karsh, "How," 59.

76 Gerges, ISIS, 103.

77 Ibid., 104.

78 Ibid. 
provided intelligence reporting on insurgent activity, and even participated in combat operations against ISI. ${ }^{79}$

The Awakening movement proved to be a critical part of the United States' counterinsurgency strategy to defeat ISI. The SOI, who only months beforehand had been fighting alongside the insurgents, understood their tactics and knew their hideouts. ${ }^{80}$ According to the Multi-National Forces-Iraq commander, General David Petraeus, attacks in and around alAnbar decreased from 1,350 in October 2006 to slightly more than 200 in August of $2007 .{ }^{81}$ Intelligence gathered from a senior al Qaeda lieutenant at the time revealed the extent of the Awakening's success. The number of the organization's operatives in Iraq had dropped from 12,000 in June 2007 to around 3,500 in early $2008 .^{82}$ The combination of US surge forces and SOI also resulted in a $90 \%$ drop in the murder rate in Baghdad. ${ }^{83}$

By 2009 the Islamic State of Iraq was all but defeated and the candidate who campaigned on a unification platform had his golden opportunity to bring Iraqis together and put an end to the sectarianism that had so long divided them. At that point, Iraq's public image as a strong, dependable state had renewed the people's confidence and helped to erode support for the insurgents. ${ }^{84}$ Rather than use the defeat of AQI/ISI to unify the country, Maliki began down a path to consolidate his power and alienate the Sunni population.

\section{Maliki's Consolidation of Power - Security and Intelligence}

Having suffered persecution under the Hussein regime, Maliki understood the value of controlling the nation's military and intelligence apparatus. In November 2010, Iraq's disparate

\footnotetext{
79 Gerges, ISIS, 104.

80 Wilbanks and Karsh, "How," 62.

81 Gerges, ISIS, 104.

82 Ibid., 105.

83 Wilbanks and Karsh, "How," 62.

84 Parker, "New," Foreign Policy, July 21, 2009.
} 
political groups reached a power sharing agreement known as the Irbil Agreement, which allowed for cabinet posts to be divided based on each party's success at the polls. ${ }^{85}$ The agreement allowed Maliki's rival coalition, Iraqiyya, to appoint the defense minister. The Prime Minister rejected their candidates, allowing him to serve as the defense minister for eight months from 2010-2011, in addition to his self-appointment as the interior minister from 2010-2014. ${ }^{86}$ During his tenure as defense minister, Maliki appointed loyal officers to key positions within the Iraqi military, and ensured that the next defense minister was an ally. ${ }^{87}$ Though Iraq's constitution provides that military officers serving at the division command level and above be approved by parliament, under Maliki no officer was subjected to parliamentary review. This circumvention was a function of both the PM's unwillingness to submit to the process as well as a reflection of parliament's general ineffectiveness. ${ }^{88}$ Maliki was never held to account for his violation of the agreement, as it had "no legal standing." 89 His opponents' only recourse was a vote of no confidence in parliament, for which they lacked sufficient support. ${ }^{90}$ Though Maliki's time as defense minister had a considerable impact on Iraq's armed forces, his influence over the military had begun years beforehand.

\section{Control Over Iraq's Security Forces}

Maliki's first major move to publicly assert his authority as commander in chief came in 2008. That spring the Iraqi government held an international investor conference in Basra, seeking to bring in businesses that would provide jobs and overcome large-scale unemployment.

\footnotetext{
85 International Institute for Strategic Studies, "Iraq: Maliki Power Grab Risks Fresh Civil War," IISS Strategic Comments 18, no. 3 (2012): 2.

86 Gerges, ISIS, 113.

87 Ibid., 115.

88 Marisa Sullivan, “Maliki’s Authoritarian Regime," Middle East Security Report 10 (April 2013): 16-17, accessed September 23, 2016, http://understandingwar.org/sites/ default/files/Malikis-Authoritarian-Regime-Web.pdf.

89 IISS, "Iraq," 3.

90 Ibid.
} 
Not surprisingly, the prevalence of Shiite militias and gangs threatened investment. ${ }^{91}$ Though violence was brewing throughout Iraq, Maliki sent 30,000 troops and police to Basra to defeat the Shiite militias, whose occupation of the port allowed them to steal around $30 \%$ of Iraq's petroleum revenue. ${ }^{92}$ Not only did they represent a financial cost to Iraq, the militias, primarily Moqtad as-Sadr's Mahdi Army, represented a direct threat by a Shia rival to Maliki's control. ${ }^{93}$ Maliki personally led the operation, called Operation Saulat al Fursan (Charge of the Knights), against the Sadrists and other militias. ${ }^{94}$

At the time, US military training teams, which were embedded within Iraqi army units throughout the country, played a critical role in training and evaluating the capabilities of the Iraqi army. Maliki made the decision to send his forces to Basra without consulting the US military, and without requesting its support. ${ }^{95}$ Despite the lack of coordination, US forces launched a major logistical operation to support the Iraqis when it became clear that they had begun executing their operation without sufficient logistical planning. Though the US provided the logistical support and the Iranians brokered the ceasefire agreement that removed Sadr's militiamen from the streets, Maliki received credit for the operation's success. ${ }^{96}$ It was a defining moment for Maliki; originally seen as weak, he had demonstrated his strength by gaining control of a major city that had been controlled by Iranian-backed Shia militias. ${ }^{97}$ In the process, he demonstrated his leadership ability and his willingness to go after Shia militias with as much determination as he pursued Sunni insurgents.

\footnotetext{
91 Mohammed M. A. Ahmed, America Unravels Iraq: Kurds, Shiites, and Sunni Arabs Compete for Supremacy (Costa Mesa, CA: Mazda Publishers, 2010), 373.

92 Ibid., 375.

93 Parker and Salman, "Notes," 73.

94 Gerges, ISIS, 109.

95 Ibid.

96 Ibid.

97 Parker and Salman, "Notes," 73.
} 
Even before the Basra operation, Maliki had been maneuvering to cement his control over Iraq's security apparatus by creating extra-constitutional structures to bypass the formal chain of command. The Iraqi military's chain of command began at the Ministry of Defense (MOD), to the Iraq Joint Headquarters, which was over all of the military branches, to the Iraqi Ground Forces Command, which had operational control of all ground units. ${ }^{98}$ Such a system was designed to ensure accurate and timely flow of information to and from the levels of command. In order to assist the PM and the military in coordinating security operations, the Maliki government and US advisors created the Office of the Commander in Chief (OCINC), which reported directly to the PM and was staffed by Maliki loyalists. ${ }^{99}$ Maliki's son Ahmed, for example, was assigned as the deputy chief of staff, given oversight of all security forces, and responsibility for the Prime Minister's security. ${ }^{100}$ The OCINC allowed Maliki to override the MOD by issuing orders directly to the provincial operations centers, and at times, passing orders directly to commanders in the field. The office gave Maliki significant operational control, but lacked a legal framework, accountability, and oversight. ${ }^{101}$ In addition to becoming a significant frustration to the US military because it bypassed the MOD and Ministry of Interior (MOI), it allowed the PM to have direct involvement in the targeting process and the movement and operations of individual units. ${ }^{102}$ The OCINC was implicated in the disproportionate targeting of Sunnis, to include the use of units that reported directly to the PM being used to arrest political rivals, which will be discussed later in this paper. ${ }^{103}$ In addition to the OCINC, Maliki

\footnotetext{
98 Sullivan, "Maliki's," 11.

99 Ibid.

100 IISS, "Iraq," 3.

101 Sullivan, "Maliki's," 11.

102 Ibid.

103 Ibid.
} 
established an additional extra-constitutional structure to increase his control over the Iraqi military.

Beginning in February 2007, Maliki established provincial operations centers around the country to bring army and police forces under one general officer in each province. Those officers maintained authority over all of the operations within their provinces. ${ }^{104}$ Since the PM had oversight over the officers assigned to these positions, those appointed were loyal to Maliki, which undermined the command and control of the MOD. ${ }^{105}$ The operations centers reported directly to the PM, and often bypassed the provincial governors and local officials. ${ }^{106}$

In April 2007 Maliki took control of another key component of Iraq's security forces. When control of the Iraq Special Operations Forces was transferred to the Iraqi government, Maliki established the Counter-Terrorism Bureau (CTB) to manage it. Though the CTB was originally designed to fall under the MOD, it answered directly to the PM. ${ }^{107}$ Its funding came from the OCINC, and like the OCINC, it had no legal framework, no accountability, and no parliamentary oversight. ${ }^{108}$ The CTB gave the PM his own armed forces, detention facilities, and judges, all of whom answered directly to the OCINC. ${ }^{109}$ Before the creation of the CTB, special forces targets were approved by a Ministerial Council for National Security committee, which included the PM, cabinet ministers, and the military Chief of Staff. The CTB bypassed that requirement, allowing the PM to direct the targeting process himself. ${ }^{110}$

\footnotetext{
104 Dodge, "State," 250.

105 Ibid.

106 Sullivan, "Maliki's," 15.

107 Dodge, "State," 250.

108 Sullivan, "Maliki's," 12.

109 Ibid.

110 Ibid.
} 
The armed forces of the CTB became known as the "Fedayeen al-Maliki," a reference to similar forces under Saddam Hussein, and were known for targeting Maliki's opponents. ${ }^{111}$ In August 2008 they were involved in an operation in Diyala, one of the most restive provinces in Iraq, and detained local SOI leaders as well as two of the provinces more powerful Sunni politicians. ${ }^{114}$ After mass arrests in Sunni communities, many of those arrested were detained in secret jails, raped, and tortured. Human rights workers, whom Maliki encouraged to report violations in the security forces, were threatened when they investigated the PM's special forces. ${ }^{115}$ Sunnis were not the only targets of Maliki's special troops; in December 2008, CTB forces arrested over 20 members of a rival Shiite party just weeks before provincial elections. ${ }^{116}$ In addition to the military, Maliki asserted his authority over the nation's intelligence apparatus.

\section{Control Over the Intelligence Apparatus}

In 2004, the CIA helped to create the Iraqi National Intelligence Service (INIS), the head and staff of which were predominately Sunni. As the predominant agency amongst Iraq's six intelligence agencies, the INIS's Sunni leadership represented a threat to the PM. ${ }^{117}$ As a result, Maliki devoted state resources to a competing agency, the Ministry of State for National Security Affairs (MSNSA), the head of which was a Shia who was trained in Iran and had been appointed by Maliki in 2006. Maliki expanded the size of the MSNSA to at least 3,500 people, until it surpassed the size of the INIS and became the predominate intelligence agency in the country. ${ }^{118}$ The head of the INIS, who had opposed Maliki, resigned in August 2009 after a bitter disagreement with the PM's office over Iranian involvement in major Baghdad attacks. ${ }^{119}$ The

\footnotetext{
111 Dodge, "State," 250.

114 Sullivan, "Maliki's," 12.

115 Parker and Salman, "Notes," 74.

116 Sullivan, "Maliki's," 12.

117 Ibid., 15.

118 Ibid.

119 Ibid., 16.
} 
Office of the Prime Minister then reportedly dismissed close to 200 seasoned Sunni intelligence officers, most of whom were replaced by Dawa party members with little experience. Some of the new officers had limited education to qualify them for their positions and, like Maliki, had spent time in exile in Iran during the Hussein regime. ${ }^{120}$ In addition to the MSNSA, Maliki maintained his ability to target information collection against his rivals through the Office of Information and Security (OIS). The OIS existed with the OCINC, reported directly to Maliki, and conducted undisclosed special intelligence missions. ${ }^{121}$ While Maliki's control over the nation's security and intelligence apparatus represented a clear physical threat to his rivals, his control over civil and independent institutions limited the ability of others to oppose his growing power.

\section{Maliki's Consolidation of Power - Civil Institutions and Parliament}

\section{Control Over the Judiciary}

In a land dominated by violence and chaos, post-2003 Iraq was not a safe place to be a member of the judiciary. Judges and their families were targeted by militants with violence and intimidation, making them susceptible to political influence. Such susceptibility served to help Maliki centralize his power, while politicizing the courts and limiting their role in balancing the executive's power. ${ }^{122}$ Maliki established a close relationship with Chief Justice Medhat alMahmoud, ${ }^{123}$ who served as "president of the Federal Supreme Court, head of the Higher Judicial Council, which oversees the judiciary, and head of the appellate court." ${ }^{124}$ Medhat

\footnotetext{
120 Sullivan, "Maliki’s," 16.

121 Ibid., 15.

122 Ibid., 19.

123 Gerges, ISIS, 115.

124 Sullivan, "Maliki's," 19.
} 
served in the judiciary since the 1960s. ${ }^{125}$ Decades of service under Saddam Hussein certainly acclimated him to executive influence in the judiciary.

Iraq's parliamentary elections on March 7, 2010 clearly demonstrated Maliki's influence over the courts. Maliki's State of Law coalition lost to the secular Iraqiyya coalition of Ayad Allawi by a count of 89 to 91 seats. Despite the fact that the elections were regarded as mostly free and fair by the United Nations and international monitors, ${ }^{126}$ Maliki dismissed the results as a conspiracy and demanded a recount. ${ }^{127}$ Despite objections from the Iraqi High Electoral Commission and the United Nations, a special judicial panel ordered the recount. ${ }^{128}$ When the recount showed no change, Maliki requested that the courts reinterpret the phrase "largest bloc" from Article 76 of the constitution. On March 24, 2010, the day before the result of the recount was released, Chief Justice Medhat ruled that the "largest bloc could mean either the electoral lists or a coalition formed after the election." ${ }^{129}$ Maliki's State of Law party and the Iraqi National Alliance, another predominately Shia bloc, formed the largest bloc and the right to form the government. ${ }^{130}$ Maliki's relationship with the judiciary allowed him to circumvent the constitution and remain in power, despite having technically lost the election. Creating further suspicion of the politicized nature of the judiciary, the same special panel that ruled in favor of Maliki's recount also upheld the disqualification of seat-winning candidates by the deBaathification commission, also known as the Accountability and Justice Commission. The fact

125 Sullivan, "Maliki's," 21.

126 Tim Arango, "Iraq Election Official's Arrest Casts Doubt on Prospect for Fair Voting," New York Times, April 16, 2012, accessed September 19, 2016, http://www.nytimes.com/2012/04/17/world/middleeast/iraq-arrest-callsfair-elections-into-question.html?_r=0.

127 Gerges, ISIS, 113

128 Sullivan, "Maliki's," 20.

129 Ibid.

${ }^{130}$ Ibid. 
that the request for disqualification was submitted by the State of Law party and that the process lacked transparency only cast further doubt on the credibility of the judiciary. ${ }^{131}$

Additional rulings over the next three years suggest the courts were subjugated to the will of the Prime Minister. In July 2010, Medhat's Higher Judicial Council ruled that parliament be deprived of its right to propose legislation. ${ }^{132}$ Under the ruling, only the cabinet, of which the PM is the leader, could propose legislation. ${ }^{133}$ Six months later, based on a constitutional interpretation request by Maliki's office, the Federal Supreme Court issued a ruling that the cabinet would be responsible for oversight of all of the nation's constitutionally independent bodies. ${ }^{134}$ According to the constitution, those bodies, which include the Iraqi High Electoral Commission, Central Bank, and the Integrity Commission, are to be monitored by parliament. ${ }^{135}$ In response to Sunni regions seeking to form federal regions in 2011, the Supreme Court refused to clarify the process for doing so. Its failure to provide constitutional clarification prevented the regions from progressing forward with their plans, helping to maintain the influence of the central government. ${ }^{136}$ In August 2013, the Supreme Court declared the law limiting the PM to two terms unconstitutional, allowing Maliki to run again in $2014 .^{137}$

\section{Exerting Control Over Parliament}

The Prime Minister's expanding influence over the legislature demonstrated the gradual erosion of Iraq's democracy under Nouri al-Maliki. In addition to the 2010 ruling depriving parliament of its right to propose legislation, the courts also removed Parliament's right to summon ministers, in a move clearly intended to protect the Prime Minister's cabinet from

\footnotetext{
Sullivan, "Maliki's," 20.

Gerges, ISIS, 114.

IISS, "Iraq," 3.

134 Sullivan, "Maliki's," 20.

135 Ibid., 21.

137 Cordesman and Khazai, Iraq in Crisis, 107.
}

136 Ibid. 
accountability. ${ }^{138}$ A Supreme Court ruling in April 2012 specified that parliament can only summon ministers "if there is clear legal evidence of criminal wrongdoing." 139 The ruling made it far more difficult for parliament to hold a no-confidence vote on the PM, by requiring that either the president initiate the vote or by one-fifth of the members of parliament initiating the motion. ${ }^{140}$ Due to the dominance of Maliki's bloc in parliament, and Iraqi President Jalal Talabani's reluctance to initiate the vote, the ruling severely limited parliament's checks on Maliki's power. ${ }^{141}$ In the spring of 2012, Maliki's opponents in parliament actively sought a noconfidence vote, but could not coalesce to generate the needed support. ${ }^{142}$ In January 2013 more than 25 members of parliament requested to question the PM, but received no response from Maliki. ${ }^{143}$ Such failed attempts to control the PM's power undoubtedly demonstrated to the Sunni population that the democratic process was not sufficient to protect them from an autocrat taking control of the country.

\section{Iraq's Independent Bodies}

Iraq's constitution created independent bodies to help preserve the country's newlyformed democratic processes. Though the constitution established that the Council of Representatives be solely responsible for monitoring these bodies, a January 2011 Federal Supreme Court ruling stripped the legislature of its oversight authority and reassigned it to the cabinet. ${ }^{144}$ The Independent High Electoral Commission (IHEC) was one such body, whose primary responsibility was to administer elections and ensure their impartiality. ${ }^{145}$ The ruling

\footnotetext{
138 Gerges, ISIS, 114.

139 Sullivan, "Maliki's," 20.

140 Ibid., 21.

141 Ibid.

142 Ibid., 27.

143 Ibid., 28.

144 Ibid., 20.

145 Ibid., 22.
} 
followed closely after Maliki's SLA party lost the spring 2010 election to Ayad Allawi's Iraqiyya coalition by two seats. ${ }^{146}$ At the time, Maliki demanded that the IHEC conduct a recount, specifically stating that the directive was based upon his authority as commander in chief. He warned the IHEC that failing to conduct the recount could result in increased violence, which was interpreted as a veiled threat that he would not peacefully cede power. ${ }^{147}$ Though the recount showed no change in the election result, Maliki reportedly believed that the commission had conspired against him.

In July 2011, members of parliament from Maliki's State of Law party launched a failed attempt to win a no-confidence vote against the IHEC based on accusations of corruption and sectarian bias. ${ }^{148}$ On April 12, 2012, two weeks before the end of his membership term, Faraj alHaidari, chief of the IHEC, was arrested on corruption charges. He was charged with illegally distributing $\$ 130$ bonuses to five employees. ${ }^{149}$ In a land where billions of dollars were stolen in corrupt dealings every year, prosecuting an official over something so insignificant appears very politically motivated. Though Maliki claimed no involvement in the arrest, he had been seeking more control over the commission after the 2011 ruling, based on his belief that the IHEC conspired to deny him a victory in the 2010 elections. ${ }^{150}$ Al-Haidari was convicted in 2012, denying him the opportunity to ever serve in government again. ${ }^{151}$ Maliki's public conflict with the IHEC sent a clear message to Iraqi society that he was not willing to respect one of the basic tenets of representative democracy.

146 Gerges, ISIS, 113.

147 Ned Parker and Caesar Ahmed, "Maliki seeks recount in Iraq elections," Los Angeles Times, March 22, 2010, accessed September 20, 2016, http://articles.latimes.com/2010/mar /22/world/la-fg-iraq-election22-2010mar22.

148 Sullivan, "Maliki's," 22.

149 Arango, "Iraq Election," New York Times, April 16, 2012.

150 Ibid.

151 Sullivan, "Maliki's," 22. 
In addition to the IHEC, the Supreme Court's 2011 ruling gave Maliki's cabinet control over Iraq's central bank. The central bank, which was designed to be largely free of political interference, was responsible for the country's monetary policy and exchange rates. Mirroring the Haidari case, the head of the bank, Sinan al-Shabibi, had opposed Maliki's attempts to exert control over the central bank. ${ }^{152}$ On October 14, 2012 the judiciary issued a warrant for alShabibi's arrest and he was suspended from his role as head of the bank. In his place, Maliki appointed an ally, Abd al-Basset Turki, who was a member of the group that investigated alShabibi. ${ }^{153}$ Shabibi's arrest represented the removal of a roadblock that granted Maliki easier access to federal reserves and greater authority over Iraq's monetary policy. ${ }^{154}$

Maliki's questionable relationship with the country's banking extended to the Trade Bank of Iraq (TBI). Though not an independent governmental body, the TBI was Iraq's largest commercial bank, with reported assets greater than $\$ 15$ billion in 2010. ${ }^{155}$ The Prime Minister ordered an investigation of TBI because of suspected violations, and personally visited the bank's headquarters along with security forces on the day the investigation was initiated. According to a British advisor for the bank, TBI had resisted attempts by government representatives to force the bank to make "improper banking transactions." 156 The head of the bank, Hussein al-Uzri, fled the country shortly after the investigation began, and days later Maliki appointed Hamida al-Jaf, a loyalist, as acting head of the bank. ${ }^{157}$ Though no independent investigation was conducted to prove which side was correct, al-Uzri has accused

Sullivan, "Maliki's," 23.

153 Ibid., 24.

154 Ibid.

155 Aseel Kami and Khalid al-Ansary, "Update 1 - Iraqi PM orders probe into state-run Trade Bank of Iraq," Reuters, June 2, 2011, accessed September 24, 2016. http://www.reuters. com/article/iraq-bankidUSLDE7511 X320110602.

156 Ibid.

157 Sullivan, "Maliki's," 30. 
Maliki of taking control of the TBI in order to finance government projects. ${ }^{158}$ Al-Uzri's accusations may be correct, as the TBI's credit to government ministries and private banks increased dramatically under al-Jaf from \$386 million in 2010 to $\$ 13$ billion in 2011. ${ }^{159}$

Established as an independent agency in 2003 after the US-led invasion, the Integrity Commission (IC) is responsible for investigating corruption within the Iraqi government. ${ }^{160}$ It has the authority to conduct investigations, but must refer cases to prosecutors in order to have charges brought. ${ }^{161}$ In a country that ranks near the very bottom of Transparency International's Corruption Perception Index, control over the integrity commission provides a powerful tool to shield one's allies and attack opponents. ${ }^{162}$ Maliki sought to use that tool by asserting influence over the commission's head, Judge Radhi al-Radhi. In early 2007, Maliki issued an order that the IC could not investigate any government minister or former minister without direct authorization from Maliki. The commission's efforts were also hampered by a ruling that allowed cabinet members to bar the investigation of their subordinates. ${ }^{163}$ According to a US embassy report in 2007, the Iraqi government withheld resources from the IC and prevented it from pursuing cases against high-ranking officials. ${ }^{164}$

In late 2007, al-Radhi announced that he was resigning from the commission due to political pressure from the Prime Minister, as well as anonymous death threats. ${ }^{165}$ His replacement, Moussa Faraj, made similar statements and was removed within weeks of taking

\footnotetext{
158 Sullivan, "Maliki’s," 31.

159 Ibid.

160 Alissa J. Rubin, "Blaming Politics, Iraqi Antigraft Official Vows to Quit," New York Times, September 7, 2007, accessed October 22, 2016, http://www.nytimes.com/2007/09/07/ world/middleeast/07iraq.html.

161 Matt Kelley, "Iraqi’s resignation hurts fight against corruption," USA Today, September 9, 2007, accessed October 22, 2016, http://usatoday30.usatoday.com/news/world/iraq/2007-09-09-iraqcorruption_N.htm.

162 Sullivan, "Maliki's," 24.

163 Kelley, "Iraqi's resignation," USA Today, September 9, 2007.

164 Sullivan, "Maliki's," 24.

165 Rubin, "Blaming Politics," New York Times, September 7, 2007.
} 
the job. ${ }^{166}$ Faraj was replaced by Judge Rahim al-Ogaili as "acting" head of the IC, which allowed Maliki to appoint him without a confirmation hearing in parliament. Ogaili resigned four years later, citing the same reason of political interference. ${ }^{167}$ Reportedly, the IC was investigating a wide-spread corruption case with links to ranking individuals in the Prime Minister's office. The government blocked the IC from prosecuting the case, prompting Ogaili's resignation. He was eventually replaced by Alaa al-Saidi, who had close ties with Dawa. ${ }^{168}$ In defiance of legislation that gave the IC and the Bureau of Financial Oversight jurisdiction over corruption cases, in April 2012 the judiciary took control over all major corruption cases, decreasing the likelihood of unbiased prosecution. ${ }^{169}$

By 2012 Nouri al-Maliki had tightened his grip on Iraq's security and intelligence apparatus, the judiciary, the parliament, and the nation's independent bodies that existed to preserve the integrity of the country's democratic systems. Early that year government leaders, including the deputy Prime Minister and the president of the autonomous Kurdish region openly claimed that Iraq was slipping back into one-man rule. ${ }^{170}$ The deputy PM was sacked when he claimed that Maliki was "worse than Saddam Hussein," while the president of Kurdistan told officials in Washington that "Iraq is facing a serious crisis...it is coming towards one-man rule."171 Ayad Allawai, a former PM and leader of the Iraqiyya party, wrote, “... already the country is slipping back into the clutches of a dangerous new one-man rule, which will inevitably

166 Sullivan, "Maliki’s," 24.

167 Joel Wing, "More on Why Iraq's Anti-Corruption Chairman Quit,” Musings on Iraq Blog, October 7, 2011, accessed October 22, 2016, http://musingsoniraq.blogspot.com/2011/10/more-on-why-iraqs-anti-corruption.html. 168 Sullivan, "Maliki's," 25.

169 Ibid.

170 Gerges, ISIS, 117.

171 IISS, "Iraq," 2. 
lead to full dictatorship." ${ }^{172}$ The inability of the government to achieve national reconciliation is one of the major factors that would come to benefit ISIS. ${ }^{173}$

\section{General Discontent with the Maliki Government}

In addition to the growing anger at Maliki's consolidation of power, Iraqis were deeply frustrated by the government's failure to provide services, as well as its human rights abuses. In 2012, six years after Maliki came to power, Iraq still suffered from high unemployment, low job security, and intermittent electricity service. ${ }^{174}$ The people resented that most of the country's high-ranking politicians had lived lives of luxury in exile while the Iraqi people suffered under the Hussein regime. They returned to run the country, but during their years in exile they had lost their connection with the people and society of Iraq. ${ }^{175}$ The Maliki government also increased the use of the death penalty, forced confessions through torture, and at times arrested women for the crimes of their male family members. Some of those women were then “imprisoned, tortured, beaten, and raped."176

By 2010, the lack of basic services, which included intermittent water and electricity, resulted in protests around the country. The protests were crushed by security services, and further protests were banned. The people's loss of one of their principle methods of communicating with their government, as well as the presence of secret police on the streets, began to resemble life under Hussein. ${ }^{177}$

\footnotetext{
172 Ayad Allawi, “Iraq's slide toward renewed violence," Washington Times, April 9, 2012, accessed September 20, 2016, http://www.washingtontimes.com/news/2012/apr/9/iraqs-slide-toward-renewed-violence/.

173 Gerges, ISIS, 117.

174 Judith S. Yaphe, "Maliki’s maneuvering in Iraq," Foreign Policy, June 6, 2012, accessed September 20, 2016, http://foreignpolicy.com/2012/06/06/malikis-manuevering-in-iraq/.

175 Gerges, ISIS, 118.

176 Ibid., 122.

177 Ibid., 114.
} 
The next February, as people rose up throughout the Arab world, tens of thousands of Iraqis protested throughout the country. The government tried to limit participation in the Arab Spring protests by banning the use of vehicles in Baghdad and other cities and banning live television coverage of the protests, which resulted in at least 29 deaths across the country at the hands of the security forces. ${ }^{178}$ The government labeled the protestors terrorists; thousands were arrested and many were tortured. ${ }^{179}$ To end the crisis, Maliki offered to cut his salary and to hold early provincial elections, a promise that was not upheld until two years after the protests ended. ${ }^{180}$ Widespread anger at the Maliki government's inability to provide services and to listen to the demands of the people was even more intense within the Sunni community, which felt that it was deliberately targeted by the Shia-dominated government.

\section{Alienating the Sunni Population}

While Prime Minister Nouri al-Maliki's general consolidation of power left the Sunni community feeling weak and marginalized, the government's direct attacks against the Sunnis only further solidified their resistance to the government in Baghdad. In the years following Maliki's ascension to power in 2006, he had numerous opportunities to unite the deeply divided nation. Rather than take steps to incorporate the minority Sunnis into the central government, his actions further alienated them. The Maliki government used the American policy of deBaathification to target the Sunni community, removing tens of thousands from their government jobs, which left a substantial number of bitter and unemployed recruits for extremist organizations. The central government also rewarded the Sunni Sahwa movement, which played a central role in the defeat of al Qaeda in Iraq, with arrests and broken promises of employment.

\footnotetext{
178 Gerges, ISIS, 121-122.

179 Zaid Al-Ali, "How Maliki Ruined Iraq," Foreign Policy, June 19, 2014, accessed September 24, 2016, http://foreignpolicy.com/2014/06/19/how-maliki-ruined-iraq/.

180 Gerges, ISIS, 121-122.
} 
Afraid of weakening the central government, the Prime Minister prevented Sunni-dominated provinces from pursuing their constitutional right of establishing federal regions. ${ }^{181}$ Finally, the offense that finally pushed the Sunnis to openly revolt and opened the door to ISIS, was the arrest of several high-profile Sunni leaders. ${ }^{182}$

\section{De-Baathification}

Under Saddam Hussein, membership in the ruling Ba'ath party was practically a requirement in order to hold a government job. ${ }^{183}$ After the 2003 invasion of Iraq, an American decision led to the dismissal of tens of thousands of Baathists in the Iraqi government in an effort to ensure that the Baath party never regained control of the country, despite the fact that many of those affected had no attachment to Baathist ideology. ${ }^{184}$ The architect of the plan was Shiite Iraqi politician Ahmad Chalabi, who used de-Baathification as a political tool that drove between fifty thousand and one hundred thousand people from their jobs. ${ }^{185}$ Prime Minister Maliki would follow suit, using de-Baathification as a tool to purge the government of political rivals.

In January 2008 the Accountability and Justice Law revised the de-Baathification process and, in a seemingly positive direction, allowed for the integration of some former Baathists into the government. It also created the Accountability and Justice Commission (AJC) to replace the de-Baathification commission. ${ }^{186}$ Despite the new name, the AJC was made up of the same members as the old commission and would continue to serve as a political tool. Weeks before

181 Kenneth M. Pollack, "Iraq Back on the Brink: Maliki's Sectarian Crisis of His Own Making," Daily Beast, December 23, 2011, accessed September 19, 2016, http://www.thedailybeast. com/articles/2011/12/23/iraq-back-onthe-brink-maliki-s-sectarian-crisis-of-his-own-making.html.

182 Gerges, ISIS, 114-115.

183 Kuoti, "Exclusion," 21.

184 Alissa J. Rubin, "Ahmad Chalabi and the Legacy of De-Baathification in Iraq," New York Times, November 3, 2015, accessed October 22, 2016, http://www.nytimes.com/2015/ 11/04/world/middleeast/ahmad-chalabi-and-thelegacy-of-de-baathification-in-iraq.html.

185 Ibid.

186 Sullivan, "Maliki's," 31. 
the March 2010 elections the AJC ruled that 511 candidates, mostly Sunnis, were barred from participating in the election because of reported Baathist links. ${ }^{187}$ The timing was suspect, as many were members of Maliki's rival Iraqiyya coalition, which would win the election prior to judicial interference. The Sunni community was outraged by the lack of transparency in the decision, with many threatening to boycott the elections. Despite the uproar, the judiciary upheld the ruling. ${ }^{188}$

Even after Iraqiyya's victory, Shiite parties attempted to use de-Baathification to eliminate candidates who had won, though a political deal averted this potential crisis. In February 2010, US General Raymond Odierno, the top US commander in Iraq, revealed that the US had intelligence confirming that AJC members Ali al-Lami and Ahmed Chalabi were "clearly influenced by Iran," and that the two had reportedly met with senior members of the Iranian regime. ${ }^{189}$ The general also stated that al-Lami had long been involved in criminal activities, as he expressed disappointment that al-Lami was in charge of a commission that had the power to blacklist candidates. ${ }^{190}$ While Maliki's precise role in the 2010 election deBaathification crisis is unknown, his use of Baathist resurgence rhetoric as a scare tactic increased his support throughout Shia-dominated areas. ${ }^{191}$

Two simultaneous de-Baathification campaigns in late 2011 again raised the ire of the Sunni community. The Ministry of Education fired 140 teachers and employees from the University of Tikrit, Hussein's home town, using the Accountability and Justice Law. The Sunni community felt unfairly targeted as reports surfaced that hundreds more from universities in

\footnotetext{
187 Gerges, ISIS, 111.

188 Sullivan, "Maliki's," 31.

189 Anne Flaherty, “US general cites direct intel linking Iraq's al-Lami, Chalabi to Iraq,” Star Tribune, February 16, 2010, accessed September 24, 2016, http://www.startribune.com/ templates/Print_This_Story?sid=84497422.

190 Ibid.

191 Sullivan, "Maliki's," 31.
} 
Sunni-dominated provinces would also be fired. ${ }^{192}$ At times, students were left without teachers until non-Baathist replacements could be found. The new less-experienced teachers were often Shiites, exacerbating tensions with Sunnis who felt they were unfairly denied employment opportunities. ${ }^{193}$

At the same time as the education campaign, Maliki conducted a purge of suspected Baathists from the security forces. More than 600 men, mostly Sunnis, were arrested as threats to the state. ${ }^{194}$ While some may have been legitimate threats, the lack of transparency, including the government's failure to produce warrants for the arrests or to identify under what legal authority the men were apprehended, cast doubts over the government's true motivation. ${ }^{195}$ Despite Maliki's talk of the Baathist threat and the subsequent arrests, the Prime Minister protected his loyalists from the de-Baathification process, even though some had been senior Baath party members. ${ }^{196}$ The feeling that the government was using the law to justify persecution of the Sunni population only further eroded any trust that existed between the two.

\section{The Awakening Movement}

By mid-2008 the Sons of Iraq, armed men from the Sunni tribes that turned against AlQaeda in Iraq as part of the Awakening movement, also known as the Sahwa movement, had helped to dramatically improve the security situation throughout Iraq. Maliki had long been concerned by the SoI's numbers and the level of US support they received, fearing that they could become a serious political force and military threat. ${ }^{197}$ That fear was evident in 2006 when Maliki told a press conference that those who carried weapons and operated outside of the law

\footnotetext{
Sullivan, "Maliki’s," 31.

193 Rubin, "Ahmad Chalabi," New York Times, November 3, 2015.

194 Sullivan, "Maliki's," 32.

195 Ibid.

196 Al-Ali, "How Maliki," Foreign Policy, June 19, 2014.

197 Gerges, ISIS, 105.
} 
would face punishment, a clear threat to the SoI. ${ }^{198}$ Despite Maliki's concerns, US support kept the SoI on the streets, offering the PM an opportunity for reconciliation. The success of the Awakening was based on the understanding that the Sunnis who participated would be given amnesty for previous offenses, and would be integrated into the security services. ${ }^{199}$

The government's opportunity to fulfill its promise to integrate the SoI into the security services and government came about earlier than many anticipated. Eager to transition more authority to the Iraqi government and increase its legitimacy, the central government took control of the Sahwa forces in 2008 . The move was interpreted by the Sunni community as a betrayal by the US. ${ }^{200}$ After the central government took control of the SoI, many members were arrested and investigated. Under US control, they had been protected and regarded as heroes, despite their actions at times being illegal. In contrast, the Iraqi government looked at them with suspicion, accusing the movement of having jihadists and Baathists within its ranks. ${ }^{201}$ On September 4, 2008 Maliki officially recognized the SoI's contribution to Iraq and announced a plan to incorporate them into the government by the end of 2009 . Out of the estimated 94,000 SoI, by April 2010 only 9,000 had been integrated into the security forces and 30,000 into other government roles. $^{202}$ Those that were given jobs were often given low pay, low rank, and the positions were often temporary. ${ }^{203}$ While low levels of education may have disqualified many from obtaining better government jobs, suspicion by those in power also limited the government's willingness to incorporate the SoI. ${ }^{204}$

\footnotetext{
198 Gerges, ISIS, 105.

199 Lesperance, "The Rise," 23.

200 Gerges, ISIS, 106.

201 Ibid.

202 Wilbanks and Karsh, "How," 68.

203 Gerges, ISIS, 106.

204 Wilbanks and Karsh, "How," 68.
} 
The Iraqi government's unwillingness to successfully incorporate the Sahwa members into the security forces and government positions represents a major failure on the part of the Maliki government. The SoI represented those in the Sunni community who had risked their lives by turning against Islamic extremist groups and driving them from their towns and cities. They had accomplished what neither US forces nor Iraqi forces had been able to achieve on their own, the defeat of $\mathrm{Al}$ Qaeda in Iraq. By prosecuting them and denying them promised employment opportunities, the Maliki government was proving that the long-held Sunni suspicions towards the Shia-dominated government were true. In addition to breaking any degree of trust that had developed, by not securing employment for the tens of thousands of young SoI men, the government was recreating the conditions that led those men into the arms of the extremists in the first place. Further exacerbating the sectarian divide was the arrest of several high-profile Sunni leaders.

\section{Perception of Iranian Influence}

While the Sunni community certainly had valid reasons to suspect that the Prime Minister's sect, along with his time in exile, made him subject to Iranian influence, the evidence is mixed. Iran sought to have Iraq controlled by friendly Shiite parties that would be amenable to Iranian interests, ${ }^{205}$ some of which were valuable members of Maliki's governing coalition. ${ }^{206}$ Maliki was well aware of Iranian ambitions, and his time in exile solidified his negative assessment of the Islamic Republic. ${ }^{207}$ Iran provided material support to Shiite militias, which were involved in sectarian violence. The Badr Brigades, for example, were "formed, trained,

\footnotetext{
205 Kenneth Katzman, “Iran's Influence in Iraq," in Surging out of Iraq?, edited by Steven J. Costel (New York: Nova Science Publishers, 2008), 169-170.

206 Reidar Visser, A Responsible End? The United States and the Iraqi Transition, 2005-2010 (Charlottesville, VA: Just World Publishing, 2010), 113.

207 Petraeus, "Tonight on Charlie Rose," Frontline, September 28, 2016.
} 
and equipped by Iran's Revolutionary Guard" during the Iran-Iraq war, and were still receiving Iranian support in post-Hussein Iraq. ${ }^{208}$ The Mahdi Army under Moqtada al-Sadr also maintained a close relationship with Iran, which proved critical in helping Maliki to obtain Sadrist support in the 2010 elections. ${ }^{209}$ Maliki may have been guilty by association, or at least may have been guilty of tacitly supporting militant Shia groups until his Basra campaign in 2008.

The political and economic relationship between Iraq and Iran improved dramatically under the new Shia government. ${ }^{210}$ Based on the antagonistic relationship under the former regime, it is hardly surprising that relations improved under Maliki. Regardless of the fact that an improved relationship with Iran brought potential economic benefits, it is easy to understand that the Sunni community's interpretation that increased Iranian involvement represented a serious threat.

\section{The Contentious Debate Over Federalism}

The targeting of Sunnis through de-Baathification contributed to the Sunni-dominated provinces of Iraq seeking the creation of autonomous federal regions. ${ }^{211}$ Al-Anbar, Salah adDin, Ninewah, and Diyala provinces all sought to apply the federalist procedures allowed for in the Iraqi constitution. ${ }^{212}$ Maliki, a firm believer that a strong central government was necessary for security and stability, ${ }^{213}$ insisted that such a move would be illegal. ${ }^{214}$ Not only would the creation of Sunni federal regions limit the power of the central government, it might encourage Basra to follow suit, which could strip away a significant amount of the government's oil

\footnotetext{
Katzman, “Iran's Influence,” 170.

Sullivan, "Maliki's," 36.

Katzman, "Iran's Influence," 172-173.

11 Cordesman and Khazai, Iraq in Crisis, 104.

212 Pollack, "Iraq Back," Daily Beast, December 23, 2011.

213 Sullivan, "Maliki’s," 9.

214 Pollack, "Iraq Back," Daily Beast, December 23, 2011.
} 
revenue. ${ }^{215}$ A member of parliament from Basra launched a federalism bid in 2008, but his inability to get the signatures of $10 \%$ of voters demonstrated the lack of popular support for the measure. ${ }^{216}$ During the following years, as the economic situation in Basra continued to decline despite its vast oil reserves, reports indicated an increased interest in the formation of a federal region. ${ }^{217}$ As a result, Baghdad's efforts to crush the Sunni federalist movement had far-reaching national implications.

In October 2011, the Salah ad-Din provincial council bypassed the requirement for a popular referendum and voted to create an autonomous federal region. The council's previous attempt at conducting a referendum had been blocked by the central government. ${ }^{218}$ The Supreme Court refused to rule in the case and President Talabani declined to assist, leading the council to go directly to the IHEC. In January 2012, when Maliki threatened to revive previous criminal charges against the provincial governor, the governor responded by withdrawing his support for federalism. ${ }^{219}$ Maliki was also able to convince Anbari officials to drop their federalism bid with promises of increased provincial powers, which never materialized. ${ }^{220}$

\section{The Arrest of Key Sunni Leaders}

December 17, 2011 was a symbolic day for Iraq and Prime Minister Maliki. That day, US forces conducted a departure ceremony in Baghdad with US Secretary of Defense Leon Panetta signifying the end to the almost nine-year occupation of Iraq. ${ }^{221}$ Maliki also returned that day from an official visit to Washington, publicly displaying the strong relationship that

\footnotetext{
Sullivan, "Maliki's," 32.

216 Visser, Responsible End, 206-207.

217 Peter Schwartzstein, “Welcome to Basrastan," Foreign Policy, July 1, 2015, accessed October 29, 2016, http://foreignpolicy.com/2015/07/01/welcome-to-basrastan-iraq-basra-secession-oil-shiite-south/.

218 Sullivan, "Maliki's," 32.

219 Ibid., 32-33.

220 Ibid., 33.

221 IISS, "Iraq," 2.
} 
remained between the two countries. ${ }^{222}$ On December $17^{\text {th }}$ the Prime Minister also sent a clear message to Iraq's Sunni community when Iraqi forces commanded by Maliki's son Ahmed placed Vice President Tariq al-Hashimi, Finance Minister Rafi al-Issawi, and Deputy PM Saleh al-Mutlaq under temporary house arrest. All three were Sunni and members of the Iraqiyya coalition..$^{223}$

Vice President al-Hashimi, leader of the largest Sunni coalition, the Iraqi Accord Front, was an ardent supporter of federalism and opposed the government's use of de-Baathification. As such, he served as a popular symbol of Sunni opposition to Maliki. ${ }^{224}$ Just two days before his house was surrounded by tanks and troops, Hashimi announced his support for the federalist movement proposed by Sunni-dominated provinces. ${ }^{225}$ Though he was placed under house arrest, Hashimi was allowed to travel to Iraq's Kurdish region. ${ }^{226} \mathrm{He}$, along with al-Issawi, were accused of being behind a failed terror attack reportedly targeting the PM, though no evidence of their involvement or of the PM as the intended target was presented to the public. ${ }^{227}$ At the time of his house arrest, three of his bodyguards were arrested and taken into custody. ${ }^{228}$ After four days the bodyguards offered a public confession that Hashimi had ordered them to conduct assassinations and bombings, and the courts issued a warrant for his arrest. ${ }^{229}$ The Ministry of the Interior requested Hashimi's extradition from Kurdish territory, which was refused, and the Kurdish authorities allowed him to flee to Turkey to escape trial. ${ }^{230}$ In January 2012 the Guardian published an article based on an interview with a security officer in the unit that

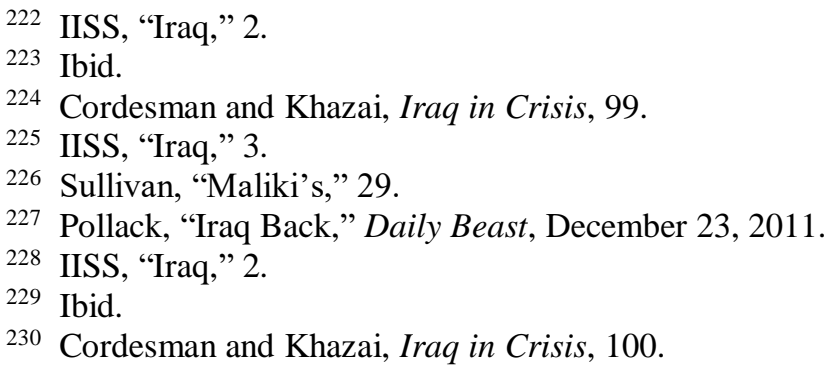


handled Hashimi's bodyguards. He described the horrific methods of torture used to extract confessions and called the claims leveled against Hashimi "absurd."231 One of the bodyguards died in custody; though the government claimed he died of an illness, photos showed that he was the victim of torture. ${ }^{232}$ Months later Hashimi was tried in absentia, convicted of operating death squads, and sentenced to death in September 2012. ${ }^{233}$ The false charges against a popular Sunni leader, as well as revelations of torture to extract confessions, further enflamed Sunni anger towards the government in Baghdad.

In December 2011, Maliki fired Deputy Prime Minister Saleh al-Mutlaq without the constitutionally mandated vote in parliament, signaling to the Sunni community a continued willingness to take unconstitutional actions based on questionable charges in order to eliminate political rivals. ${ }^{234}$ As a Sunni and strong proponent of a national unity government, Mutlaq had been a longtime rival of Maliki. In October 2011, he threatened Maliki with public protests if the de-Baathification operations continued. ${ }^{235}$ In an interview two months later he stated that "Iraq's political process is going towards a dictatorship." ${ }^{, 236}$ Immediately preceding his firing, Mutlaq joined the Iraqiyya boycott of the government in protest of Hashimi's arrest. ${ }^{237}$ On December $21^{\text {st }}$, Maliki gave a press conference demanding that the Kurds turn Hashimi over to the authorities and that his decision regarding Mutlaq be respected. He threatened to take further action against Iraqiyya party leaders if they failed to cooperate with him, while also threatening

231 Ghaith Abdul-Ahad, "Corruption in Iraq: 'Your son is being tortured. He will die if you don't pay," Guardian, January 15, 2012, accessed October 22, 2016, https://www.theguardian. com/world/2012/jan/16/corruption-iraq-sontortured-pay.

232 IISS, "Iraq," 2.

233 Sullivan, "Maliki's," 29.

234 Pollack, "Iraq Back," Daily Beast, December 23, 2011.

235 Cordesman and Khazai, Iraq in Crisis, 97.

236 Ibid.

237 Sullivan, "Maliki's," 29. 
to rule "as a majoritarian government without the Sunnis."238 After much public debate, Mutlaq was allowed to return to the cabinet in mid-2012, though the incident was hardly forgotten by the Sunni community. ${ }^{239}$

Rafi al-Issawi, a moderate Sunni, was appointed Minister of State for Foreign Affairs in 2006, only to withdraw in 2007 over frustrations that the Prime Minister was failing to eliminate Shia militias. ${ }^{240}$ He returned to the government in July 2008 as the Deputy PM, and later became the Finance Minister after the 2010 elections. While Issawi was serving as Deputy PM, Maliki expressed concern to the US military that Issawi may have ties to extremists. In August 2010, General Odierno took a rare step of sending Maliki a letter confirming that a US intelligence review of the charges revealed that they were baseless. ${ }^{241}$ In December 2011 Issawi joined Sunni government officials in their boycott after Hashimi's arrest and publicly accused Maliki of dictatorial tendencies, ${ }^{242}$ to which the PM's office responded by accusing him of links to AQI. ${ }^{243}$ In December 2012, a year after his temporary house arrest, Issawi and 12 of his bodyguards were arrested, leading to protests throughout the Sunni-dominated provinces of Anbar, Ninewa, and Salah ad-Din. ${ }^{244}$ Around 60,000 people rose up to protest in Fallujah and 100,000 in Ramadi. ${ }^{245}$ The protestors demanded an end to the anti-terrorism law which they claimed was biased against Sunnis, and for the release of Sunni detainees who had been held without charges under the law. $^{246}$

\footnotetext{
238 Pollack, “Iraq Back,” Daily Beast, December 23, 2011.

39 Cordesman and Khazai, Iraq in Crisis, 97.

240 Ibid., 101.

241 Jack Healy and Michael R. Gordon, “A Moderate Official at Risk in Fracturing Iraq," New York Times, December 30, 2011, accessed October 22, 2016, http://www.nytimes.com/ 2011/12/31/world/middleeast/rafe-alessawi-a-moderate-in-an-increasingly-polarized-iraq.html.

242 Ibid.

243 Cordesman and Khazai, Iraq in Crisis, 101.

244 Gerges, ISIS, 123.

245 Dodge, "State," 242.

246 Sullivan, "Maliki's," 28.
} 
In 2013 Ahmed al-Alwani, a Sunni member of Parliament, created a resistance camp near Ramadi in protest to the government. ${ }^{247} \mathrm{He}$ was largely viewed as a legitimate politician and public critic of Maliki who called for peaceful protests. ${ }^{248}$ Though no clear link was established, reports suggest that a militant attack on the Iraqi Army's $7^{\text {th }}$ Division command center prompted Maliki to respond by sending security forces to dismantle the protest camp under the auspices that it was sheltering Islamic militants. ${ }^{249}$ The security forces raided Alwani's home in Ramadi, arresting Alwani on terrorism charges and killing his brother and five guards. ${ }^{250}$ His wife and 12-year-old son were injured in the raid, which fueled further Sunni anger. ${ }^{251}$ The raid triggered an uprising in Anbar. At a protest in Fallujah one of the leaders, Sheikh Ahmed al-Tamimi stated, "The war has begun. I call on young people to carry their weapons and prepare. We will no longer allow any army presence in Fallujah."252 Thus began the battle of Fallujah and its fall into ISIS' hands.

\section{Syria, Jail Breaks, and the Resurgence of ISI}

Just three years before the Islamic State took control of Fallujah, such an event would have seemed almost impossible. Driven by the SOI and USF from the areas they once controlled, ISI was a shadow of its former self. By June 2010 , " $80 \%$ of ISI's 42 primary leaders had been killed or captured." ${ }^{253}$ Those that remained had no safe haven, but their luck was about to change.

Kuoti, "Exclusion," 25.

248 Cordesman and Khazai, Iraq in Crisis, 97.

249 Ibid., 112.

250 Ibid., 97.

251 Yasir Ghazi and Tim Arango, "Deadly Shootout and Arrest in Iraq Set Off Sunni Protests," New York Times, December 28, 2013, accessed September 24, 2016, http://www.nytimes.com/2013/12/29/world/ middleeast/iraq.html?_r=0.

252 Ibid.

253 Lesperance, “The Rise," 20. 
The spring of 2011 appeared to bring the promise of positive change to the Arab world, though in Syria and other countries that illusion would quickly be replaced by a dark and destructive reality. The primarily Sunni revolt against the Shia minority regime in Syria threw open the door for ISI to find a new home. Abu Bakr al-Baghdadi, who had taken command of ISI after his predecessor's death in April 2010, grew the organization by enlisting new members from former Baathist officers to former members of Iraq's secret services. ${ }^{254}$ The lawless environment in Syria provided him with an ideal opportunity to recruit, train, and organize forces just across the border from al-Anbar. ${ }^{255}$ By early 2011, Baghdadi was sending fighters into Syria to gain combat skills, integrate into the Sunni community, and recruit new members. ${ }^{256}$ Maliki's support for the Assad regime at the time only led to greater mistrust within the Sunni community, fueling recruitment for ISI, and resulting in protests and the return of high levels of violence. $^{257}$

In June 2012 Baghdadi announced an operation that would further revitalize his organization, while demonstrating the incompetence of the Iraqi government. Operation "Breaking the Walls" defined the group's top priority at the time, releasing Muslim prisoners. ${ }^{258}$ The first prison break occurred in September 2012, when ISI fighters freed 100 inmates from a prison in Tikrit. The following summer the group freed between 500-1000 inmates from the notorious Abu-Ghraib prison, to include some of the group's top leaders. ${ }^{259}$ The Maliki government's failure to protect the prison system suggests a breakdown of the justice system

\footnotetext{
254 Malcom Nance, Defeating ISIS (New York: Skyhorse Publishing, 2016), 19.

255 Liz Sly, "In Iraq, a Sunni revolt raises specter of new war," Washington Post, January 6, 2014, accessed October 12, 2016, https://www.washingtonpost.com/world/middle_east/in-iraq-a-sunni-revolt-raises-specter-of-newwar/2014/01/06/280f9216-7714-11e3-b1c5-739e63e9c9a7_print.html.

256 Nance, Defeating ISIS, 19.

257 Gerges, ISIS, 123

258 Aki Peritz, “The Great Iraqi Jail Break,” Foreign Policy, June 26, 2014, accessed October 28, 2016, http://foreignpolicy.com/2014/06/26/the-great-iraqi-jail-break/. 259 Ibid.
} 
itself. Without the ability to hold criminals accountable for breaking the law, Iraq risked its laws becoming meaningless, and the government itself losing legitimacy. From a more practical standpoint, the government's failure to secure its prisons gave ISI access to additional leaders, recruits, and weapons and explosives experts. ${ }^{260}$

In April 2013 Baghdadi announced the merger of ISI and al-Nusra Front, another Sunni extremist group fighting the Assad regime in Syria, to form the Islamic State of Iraq and al-Sham (ISIS). The al-Nusra leadership refused to be subjugated to ISI's control, prompting al-Qaeda leader Ayman al-Zawahiri to issue a directive that ISI remain in Iraq. Baghdadi refused, and alQaeda broke with ISIS in February 2014. ${ }^{261}$ Four months later, the group that had been all but defeated during the surge would take control of Iraq's second largest city and declare itself a caliphate now to be called "The Islamic State."262 Not only did the Maliki government fail to take advantage of the dramatically weakened state of ISI in 2008 and to protect its prison system, it also failed to develop a military solution sufficient to deal with the Islamic extremist threat.

\section{Military Matters}

Prime Minister Maliki and his government had direct control over two military-related decisions that dramatically impacted ISIS' ability to take and hold territory in Iraq. First, Iraqi officials had the opportunity to extend the American troop presence in Iraq. Even President Obama, who had run on a platform of pulling all US troops out of Iraq, recognized the risk in doing so, and was ready to put that promise on hold for the sake of Iraq's stability. Maliki's government rejected that option, placing their confidence in their own armed forces. ${ }^{263}$

\footnotetext{
260 Peritz, "Great Iraqi Jail Break," Foreign Policy, June 26, 2014.

${ }^{261}$ Lesperance, "The Rise," 22-23.

262 Nance, Defeating ISIS, 19.

263 Yochi J. Dreazen, “U.S. Troops Are Leaving Because Iraq Doesn't Want Them There,” Atlantic, October 21, 2011, accessed September 20, 2016, http://www.theatlantic.com/ politics/archive/2011/10/us-troops-are-leavingbecause-iraq-doesnt-want-them-there/247174/.
} 
Secondly, the Maliki government willfully decided not to invest appropriately in its armed forces, filling the ranks with political appointees and allowing rampant corruption. ${ }^{264}$

\section{Denial of the US Troop Extension}

In December 2008, President George W. Bush signed a Status of Forces Agreement (SOFA) with Iraq, agreeing to the full withdrawal of American forces by the end of $2011 .^{265}$ As that date approached, the Obama administration understood the dangers present if the US were to withdrawal its forces before the Iraqis were capable of fully protecting themselves. Despite its role in creating the situation in Iraq, the US military played an important role in building consensus amongst Iraq's disparate political groups. ${ }^{266}$ Even in 2011, the presence of US forces helped to prevent the resurgence of insurgent groups. As a result, the administration publicly and privately tried to convince the Iraqi government to leave a residual force behind, from the minimal number of 3,000 proposed by President Obama to the 10,000-15,000 range suggested by US military commanders. ${ }^{267}$ Even a small US military presence would have maintained US access to key infrastructure that would have facilitated the return of troops to support the Iraqi government if necessary. ${ }^{268}$ Whether Maliki fully understood the threat growing across his border, or how woefully incapable his forces were, is debatable, but he did understand that the Iraqi people would not stand for an American military presence in Iraq after 2011.

In a March 2009 interview, Maliki stated that he did not want US forces to withdraw from areas until they were completely secure, but by 2011 such a statement would have been political suicide. $^{269}$ Even if Maliki had wanted the troop extension offered by President Obama,

264 Cordesman and Khazai, Iraq in Crisis, 134-135.

265 IISS, "Iraq," 2.

266 Celso, "Zarqawi's Legacy," 27.

267 Dreazen, "U.S. Troops," Atlantic, October 21, 2011.

268 Petraeus, "Tonight on Charlie Rose," Frontline, September 28, 2016.

269 Ahmed, America Unravels, 413. 
it would have been nearly impossible to achieve due to the almost unanimous support across Iraqi political parties for the US departure by the end of 2011. ${ }^{270}$ Ayad Allawi, the pro-American Iraqi political leader, acknowledged that Iraqi forces were not capable of standing alone, yet he did not support the troop extension. ${ }^{271}$ Some Shiite groups, like the Sadrists, threatened a return to violence if US forces remained beyond the end of the year. Only the Kurds offered some support, but even that support was far from unanimous. ${ }^{272}$ Knowing that allowing US troops to remain would be the end of his political career and would risk plunging Iraq deeper into violence, Maliki took a hardline against the US proposal. He used the opportunity to portray himself as a strong Iraqi nationalist, standing firm against the United States. ${ }^{273}$ Maliki set a condition for the troop extension that he knew was untenable for the US government, demanding that US troops would have no immunity and would thus be subject to prosecution in the Iraqi judicial system. ${ }^{274}$ Unable to reach an agreement, the last US troops left Iraq in December 2011 and the Iraqi security forces assumed full responsibility for their nation's protection.

\section{State of the Iraqi Military}

As Toyota pickup trucks and hundreds of ISIS fighters crossed the desert to Fallujah in early 2014 they faced a sovereign nation that boasted a force of 271,000 troops. ${ }^{275}$ It seems to defy logic that the world's most powerful military had spent nearly nine years and billions of dollars to train and equip the Iraqi forces only to see them melt away in the face of a small and lightly-armed contingent, but numbers rarely tell the whole story.

\footnotetext{
270 Dreazen, “U.S. Troops,” Atlantic, October 21, 2011.

271 Ibid.

272 Ibid.

273 Dodge, "State," 246.

274 Dreazen, “U.S. Troops,” Atlantic, October 21, 2011.

275 Sam Jones and Borzou Daragahi, “Iraq's security forces ill-equipped to face militants," Financial Times, July 10, 2014, accessed September 28, 2016, https://www.ft.com/content /a089e41e-081c-11e4-9afc-00144feab7de.
} 
The Iraqi military struggled with low morale, poor leadership, and corruption that proved to be a major hindrance. Its ranks had been filled with Maliki’s loyal political appointees, limiting the army's operational capacity. ${ }^{276}$ Promotions and appointments were at times openly sold, or were awarded based on family or sectarian connections, leading to a rapid decline in the quality of Iraq's military leadership. ${ }^{277}$ Despite high personnel numbers, the army lacked critical intelligence and logistics capabilities, and Maliki's Office of the Commander in Chief significantly weakened the chain of command. ${ }^{278}$ When the military, of which Maliki had taken so much personal ownership, proved highly unreliable, he turned to foreign-backed Shia militias and volunteers to defend the capital. ${ }^{279}$ The government's use of Shia militias confirmed for many Sunnis that the government could not be trusted to protect them.

Iraqi officers with whom the author worked closely in 2010-11 expressed tremendous concern about the withdrawal of American troops. They prophetically told of how Iraq would fall apart without American forces to hold it together. They accepted what their government refused to accept, that the Iraqi forces were not capable of standing on their own at the end of 2011. As reported throughout Iraq, as soon as portions of the author's base were transitioned to the Iraqi military in mid-2011, the buildings were immediately looted. ${ }^{280}$ Such a lack of discipline, inability to provide security, and lack of ethos reflect the state of the Iraqi military that was left to defend the nation's porous borders.

\footnotetext{
276 Jones and Daragahi, “Iraq's security forces,” Financial Times, July 10, 2014.

277 Cordesman and Khazai, Iraq in Crisis, 134-135.

278 Jones and Daragahi, “Iraq's security forces," Financial Times, July 10, 2014.

279 Al-Ali, "How Maliki," Foreign Policy, June 19, 2014.

280 Cordesman and Khazai, Iraq in Crisis, 134-135.
} 


\section{ISIS Exploitation of Iraqi Weakness}

Years of targeted oppression by the Shia-dominated government made Iraq's Sunni provinces highly susceptible to ISIS influence and subjugation. By 2013, Sunni protests had come to include a mixture of unarmed citizens and organized armed groups. Iraqi security forces tried to root out the insurgents, further deepening the conflict. ISIS took advantage of the opportunity to claim that it stood with the Sunni population, which increased the group's support in Sunni-controlled areas. ${ }^{281}$ The violence in al-Anbar began the first week of January 2014 after government troops stormed the protest camp in Ramadi. The incident proved to be the straw that broke the camel's back, as Sunni resistance reached its highest level since 2008. Some Sunnis allied themselves with ISIS, while others rallied against it. A three-way struggle ensued, with almost all Sunnis willing to fight the Iraqi army, and some fighting ISIS to keep them from returning to the lands from which they had been expelled during the Awakening. ${ }^{282}$

After an increase in protests resulted from the raid on the camp, Maliki withdrew the army from Fallujah and Ramadi to quell the anger at the government. Responsibility to protect the cities was given to an Iraqi police force that was weak and corrupt. The first week of January 2014, ISIS captured the two cities with around 75-100 pickup trucks and less than 1000 men. ${ }^{283}$ The fact that many people harbored stronger hatred towards the government than towards ISIS, which had committed brutal atrocities against the Sunni community, demonstrates the extreme level of distrust felt towards the government in Baghdad. ${ }^{284}$ Rather than address the grievances expressed by the Sunni community, Maliki labeled almost every Sunni complaint as terrorism

\footnotetext{
281 Gerges, ISIS, 125

282 Sly, "In Iraq," Washington Post, January 6, 2014.

283 Cordesman and Khazai, Iraq in Crisis, 180.

284 Yasir Ghazi and Tim Arango, "In Iraqi City Under Siege, More Support for Militants Than Officials," New York Times, January 7, 2014, accessed October 12, 2016, http://www. nytimes.com/2014/01/08/world/middleeast/in-iraqicity-under-siege-more-support-for-militants-than-officials.html.
} 
and linked it to al-Qaeda, making it far more difficult for moderates to lend their support to the government. ${ }^{285}$ While the government was shelling Fallujah, an effort that only made resentment towards the government worse, ISIS fighters brought food and fuel to the people. Unlike the impression left at the height of the insurgency, the ISIS fighters gave the appearance of being more accommodating to local needs and customs in order to gain the support of the people. ${ }^{286}$

The Maliki government's missteps in Anbar only continued to erode the government's chance of reclaiming its westernmost province. Rather than incorporate a strategy like the Sahwa councils, the central government recruited fighters from Shia-dominated parts of Iraq to fight in Anbar. Residents of Fallujah were outraged and fearful after seeing images of Shiite men at army recruiting stations in Baghdad holding Hezbollah flags and volunteering to fight in Anbar. $^{287}$ In late January Maliki announced a curious decision reached by his cabinet to create three new provinces in Iraq, one of which had Fallujah as its capital. In addition to the fact that Fallujah was already under ISIS control at the time, no Sunni group had asked for the division of Anbar province, leading the move to be interpreted as an attempt by the government to gain greater control over the Sunnis. ${ }^{288}$

In June 2014 ISIS cemented its position in Iraq by capturing its second-largest city, Mosul. In the face of ISIS' advance, Iraqi troops abandoned their posts and fled the city, allowing the militants to easily take control of Mosul and its hinterlands. ${ }^{289}$ During their hasty and unjustified withdrawal, the army left behind high-quality equipment provided by the US and its allies, leaving it to the insurgents they would face in battle again two years later. ${ }^{290}$ Iraq's

285 Ghazi and Arango, “In Iraqi City,” New York Times, January 7, 2014.

286 Ibid.

287 Ibid.

288 Cordesman and Khazai, Iraq in Crisis, 113-114.

289 Celso, "Zarqawi's Legacy," 28.

290 Jones and Daragahi, “Iraq's security forces,” Financial Times, July 10, 2014. 
military failed miserably at its most important mission, to protect the people and sovereignty of Iraq. Much of the responsibility for that failure rests with the corrupt and dysfunctional government in Baghdad.

\section{External Factors Affecting Iraq During Maliki's Rule}

Though this paper focuses specifically on the Iraqi government's role in the resurgence of extremism, and is not intended to provide every detail of the story of ISIS' creation, it is critical to understand the presence of key variables that existed outside of Maliki's control. Lesperance identifies three factors that led to the creation of ISIS, two of which are external to the Iraqi government. He lists the radicalization of detainees at Camp Bucca, the battlefield experiences jihadists gained in Syria, and Nouri al-Maliki's sectarian policies as the primary contributors to ISIS' existence. ${ }^{291}$ This section of the paper serves to shed light on the bigger picture of events in Iraq during the discussed time period, and to remind the reader that Maliki was not operating in an isolated bubble free from outside influences. Maliki cannot be blamed entirely for the genesis of the Islamic State, but this paper argues that despite the other factors at play in Iraq, Maliki remains accountable for the decisions that he made and the ramifications that followed.

Despite the media focus on Iranian influence in post-2003 Iraq, Saudi Arabia represented a significant threat to the stability of the Shia-majority government in Baghdad. US ambassador Christopher Hill wrote in mid-2009 that Iraqi officials viewed Saudi Arabia as one of its greatest international threats based on its wealth, strong anti-Shia sentiments, and belief that a Shiadominated government would further empower Iran's regional ambitions. ${ }^{292}$ The ambassador reported that Saudi Arabia used significant resources to support Sunni politicians and gain

\footnotetext{
291 Lesperance, "The Rise," 23.

292 Simon Tisdall, "WikiLeaks Cables: Saudi Arabia rated a bigger threat to Iraqi stability than Iran," Guardian, December 5, 2010, accessed November 8, 2016, https:/www.theguardian. com/world/2010/dec/05/wikileakscables-saudi-meddling-iraq.
} 
leverage over Sunni tribes, as well as using media attacks against Shia parties. ${ }^{293}$ Operating in an environment in which one of Iraq's wealthiest and most powerful neighbors actively sought his government's failure undoubtedly furthered Maliki's distrust of the Sunni community and may have motivated some of his anti-Sunni policies.

While Saudi Arabia and Iran may have been important contenders for influence in Iraq, no country had a greater influence on the rise in sectarianism in Iraq than the United States. The American tendency to view most issues in Iraq through a sectarian lens helped to ignite the civil war that tore Iraqi society apart. The US policies of de-Baathification and the disbandment of the Iraqi army signaled an abrupt change of fortune for the minority Sunni community. These policies put tens of thousands of Sunnis out of work, providing ample recruits for groups such as al Qaeda. De-Baathification would also become an effective tool used by Maliki and others to target political rivals. Many of the former Baathist Sunnis who lost their jobs ended up in American detention facilities where they were radicalized before being released, feeding the insurgency against which Maliki’s forces had to contend.

Camp Bucca, the US military detention facility located outside the town of Garma in southern Iraq, also played a key role in the formation of ISIS. In 2005, American forces captured Abu Bakr al-Baghdadi and held him for four years in the prison at Camp Bucca. ${ }^{294}$ Such prisons later earned the title "terrorist universities," as hardened jihadists, such as al-Baghdadi, trained and radicalized other prisoners. ${ }^{295}$ Many of those prisoners were only "suspicious looking military-aged males" when they entered the facility that held 24,000 prisoners at the height of the

293 Tisdall, “WikiLeaks,” Guardian, December 5, 2010.

294 Terrence McCoy, "How the Islamic State evolved in an American prison," Washington Post, November 4, 2014, accessed November 9, 2016, https://www.washingtonpost.com/news /morning-mix/wp/2014/11/04/how-anamerican-prison-helped-ignite-the-islamic-state/. 295 Ibid. 
surge. ${ }^{296}$ The jihadists held tremendous sway inside the facility, forcing the other prisoners to submit to their extremist views.

Nine of the Islamic State's top leaders were held at Camp Bucca, where collaboration between two seemingly incompatible groups took place. The jihadists formed a symbiotic relationship with secular Baathists, combining their skills and experience to produce a disciplined force under the influence of strongly-held religious beliefs. When released, many of the men held at Camp Bucca left with a mixture of hatred and extremism that made them perfect warriors for Baghdadi's growing army. ${ }^{297}$ As such, the failure of American forces to comprehend what was happening within the walls of their prison played a critical role in the formation of the Islamic State.

Perhaps the final American failure that contributed to the rise of ISIS was its allegiance to Maliki despite clear warning signs that he was leading the country in a dangerous direction. American officials were undoubtedly aware of Maliki's sectarian policies and consolidation of power, yet they remained loyal. Khedery suggests that American officials as high as the Vice President insisted that Maliki was their only option and threw their full support behind him. ${ }^{298}$ By signaling to the Iraqi people that it was an unwavering ally of Maliki, the US became complicit in the actions that alienated the Sunni population and eventually drove them to violently resist the government in Baghdad.

During his time in office, Maliki faced external factors that consistently worked to prevent the unification of Iraq. The Iranians sought a friendly Shia-led government in Baghdad that would be responsive to their needs. As Iran's rival power in the region, Saudi Arabia

\footnotetext{
296 McCoy, "How the Islamic State," Washington Post, November 4, 2014.

297 Ibid.

298 Khedery, "Why we stuck with Maliki," New York Times, July 3, 2014.
} 
refused to accept such a situation, using its tremendous resources to exert influence in Sunni areas of Iraq. The 2011 revolt in Syria could not have come at a worse time for Maliki. The power vacuum created in parts of Syria gave new life to a Sunni extremist movement that was nearly extinguished by 2010 . These factors, in addition to the multiple missteps by the American occupying force in Iraq, presented continual challenges to the Maliki government and certainly made any attempts at national unification far more difficult.

Considering the external factors working against Maliki, it is fair to question whether he was truly responsible for his actions or if any other prospective leader may have been forced into the same mold. Ned Parker, for example, argues that the formation of "a Shiite-led authoritarianstyle state" was inevitable based on Iraq's history and a perceived Iraqi preference for security over freedom. ${ }^{299}$ It is highly possible that another Shia leader would have taken a path similar to Maliki's. The outside variables affecting Iraq likely would not have changed with a different PM; American officials would have still viewed Iraq through sectarian lenses, regional governments would have maintained the pursuit of their interests in Iraq, and the chaos in Syria post-2011 would have still provided a safe haven for the growth of extremism. Despite those unfavorable variables, it is also possible that another leader would have seen the value in including the Sunni population in the government in a meaningful way, thus providing a political recourse to those who eventually took up arms under Maliki. Such a leader might have built bridges through which the inherent sectarian mistrust may have eventually been healed, at least to the point that cooperation for the benefit of all groups was possible. Unfortunately for Iraq, Nouri al-Maliki was not that leader. Regardless of what others might have done or not done in his place, the premise of this paper is that Maliki had choices. He made decisions that had real

299 Ned Parker, "Machiavelli in Mesopotamia: Nouri al-Maliki Builds the Body Politic," World Policy Journal 26, no. 1 (Spring 2009): 25, accessed August 16, 2016, Duke University Press Journals Online. 
consequences on sectarian relations in Iraq. Some of those decisions may reflect his personal beliefs and experiences that produced a deep-seated mistrust of the Sunni community, as well as his Shia rivals. Other decision points, such as whether or not to accept the US troop extension, promised negative consequences regardless of which direction he chose. Nonetheless, he made decisions that had a very real impact on the resurgence of Islamic extremism and the establishment of ISIS in Iraq.

\section{Conclusion}

The sectarian policies and leadership decisions of the Nouri al-Maliki government set the conditions for the resurgence of Sunni Islamic extremism in Iraq and the development of the Islamic State caliphate. Long the dominant power in Iraqi society and politics, the country's minority Sunni population faced a rapid change of status after the 2003 US-led invasion. From the beginning, Sunni leaders found themselves excluded from the government, to include the committee formed to draft the nation's new constitution. ${ }^{300}$ Rather than seek to integrate Sunni leaders into the government, Prime Minister Maliki sought to consolidate his power by eliminating rivals and alienating the Sunni community. His Office of the Commander in Chief, along with additional extra-constitutional structures, allowed him to bypass the formal military chain of command and gave him direct access to the military's targeting process. ${ }^{301}$ Maliki's influence over the judiciary was evident in numerous court rulings that expanded his powers while stripping away the powers of the legislature. ${ }^{302}$ While many of Maliki's maneuvers were threats to Iraqi democracy as a whole, many of his policies directly targeted the Sunni minority.

\footnotetext{
300 Kuoti, "Exclusion," 22.

301 Sullivan, "Maliki's," 11.

302 Gerges, ISIS, 115.
} 
The suffering of Maliki's family under Saddam Hussein and Maliki's decades of resistance to the Baathist government shed light on the reasoning behind his suspicions towards the Sunni community and his efforts to limit their influence in Iraqi politics. ${ }^{303}$ The policy of deBaathification, begun by American authorities shortly after the invasion, became an important tool of Maliki's to remove rivals and replace them with loyalists. ${ }^{304}$ The policy was heavily biased towards Sunnis, for whom membership in the Baath party was all but a prerequisite for government employment in the Hussein regime. ${ }^{305}$ Maliki's unfulfilled promises to those who risked their lives as part of the Awakening movement also sent a clear message to the Sunni community that the central government in Baghdad had no intention of incorporating them into the government in a meaningful way. ${ }^{306}$ The perception of growing Iranian influence, the denial of their right to form federal regions, and the arrests of key Sunni leaders on questionable charges ensured that there was no trust left for the central government by 2013. Maliki's policies had pushed the Sunni community into an impossible situation, side with an untrustworthy Shiadominated government or with the Islamic extremists that only a few years beforehand had subjugated the Sunnis with a strict interpretation of sharia law.

In addition to his efforts to consolidate power and alienate the Sunni community, Maliki made key missteps regarding security in Iraq that opened the door to ISIS' military advance. Despite the Obama administration's desire to pull out of Iraq, it recognized that leaving prematurely could have disastrous consequences. As a result, the US offered to leave a small contingent in Iraq, but the Iraqi government refused the offer and placed its future in the hands of

\footnotetext{
303 Parker and Salman, "Notes," 67.

304 Sullivan, "Maliki's," 31.

305 Kuoti, "Exclusion," 24.

306 Gerges, ISIS, 105-111.
} 
the Iraqi military. ${ }^{307}$ De-Baathification, corruption, and the appointment of political appointees in key positions had produced an incompetent and undisciplined armed forces that fled in the face of an ISIS advance. ${ }^{308}$ In the end, Maliki's efforts to be the new strongman of Iraq resulted in a deeply divided society, a dysfunctional government, a hollow military, and the embarrassing loss of sovereign Iraqi territory to the Islamic State.

307 Dreazen, “U.S. Troops," Atlantic, October 21, 2011.

308 Cordesman and Khazai, Iraq in Crisis, 134-135. 


\section{Bibliography}

Abdul-Ahad, Ghaith. "Corruption in Iraq: 'Your son is being tortured. He will die if you don't pay." Guardian, January 15, 2012. Accessed October 22, 2016. https://www.theguardian. com/world/2012/jan/16/corruption-iraq-son-tortured-pay.

Ahmed, Mohammed M.A. America Unravels Iraq: Kurds, Shiites, and Sunni Arabs Compete for Supremacy. Costa Mesa, CA: Mazda Publishers, 2010.

Al-Ali, Zaid. "How Maliki Ruined Iraq." Foreign Policy, June 19, 2014. Accessed September 24, 2016. http://foreignpolicy.com/2014/06/19/how-maliki-ruined-iraq/.

Allawi, Ayad. "Iraq's slide toward renewed violence." Washington Times, April 9, 2012. Accessed September 20, 2016. http://www.washingtontimes.com/news/2012/apr/9/iraqsslide-toward-renewed-violence/.

Arango, Tim. "Iraq Election Official's Arrest Casts Doubt on Prospect for Fair Voting." New York Times, April 16, 2012. Accessed September 19, 2016. http://www.nytimes.com/ 2012/04/17/world/middleeast/iraq-arrest-calls-fair-elections-into-question.html?_r=0.

Carroll, Rory. "Sunnis admit poll boycott blunder and ask to share power." Guardian, February 14, 2005. Accessed October 29, 2016. https://www.theguardian.com/world/2005/ feb/15/iraq.rorycarroll.

Celso, Anthony N. “Zarqawi’s Legacy: Al Qaeda’s ISIS 'Renegade.” Mediterranean Quarterly 26, no. 2 (June 2015): 21-41. Duke University Press Journals Online.

Cordesman, Anthony H. and Sam Khazai. Iraq in Crisis. Lanham, MD: Rowman \& Littlefield, 2014.

Crocker, Ryan. "Losing Iraq." Transcript by Sarah Childress. Frontline. PBS, July 10, 2014. http://www.pbs.org/wgbh/frontline/article/ryan-crocker-our-national-security-is-at-stakeright-now/.

Dodge, Tody. "Iraq doesn't have to fall apart. It can be reformed." Guardian, June 13, 2014. Accessed November 11, 2016. https://www.theguardian.com/commentisfree/2014/jun/ 13/iraq-isis-terrible-decisions-2003-new-course-state-survive.

Dodge, Toby. "State and society in Iraq ten years after regime change: the rise of a new authoritarianism." International Affairs 89, no. 2 (March 2013): 241-257. Wiley Online Library.

Dreazen, Yochi J. “U.S. Troops Are Leaving Because Iraq Doesn't Want Them There.” Atlantic, October 21, 2011. Accessed September 20, 2016. http://www.theatlantic.com/ politics/archive/2011/10/us-troops-are-leaving-because-iraq-doesnt-want-them-there/247174/. 
Flaherty, Anne. "US general cites direct intel linking Iraq's al-Lami, Chalabi to Iraq." Star Tribune, February 16, 2010. Accessed September 24, 2016. http://www.startribune.com/ templates/Print_This_Story?sid=84497422.

Gerges, Fawaz A. ISIS: A History. Princeton, NJ: Princeton University Press, 2016.

Ghazi, Yasir and Tim Arango. "Deadly Shootout and Arrest in Iraq Set Off Sunni Protests." New York Times, December 28, 2013. Accessed September 24, 2016. http://www.nytimes. com/2013/12/29/world/middleeast/iraq.html?_r=0.

Ghazi, Yasir and Tim Arango. "In Iraqi City Under Siege, More Support for Militants Than Officials." New York Times, January 7, 2014. Accessed October 12, 2016. http://www. nytimes.com/2014/01/08/world/middleeast/in-iraqi-city-under-siege-more-support-formilitants-than-officials.html.

Healy, Jack and Michael R. Gordon. "A Moderate Official at Risk in Fracturing Iraq." New York Times, December 30, 2011. Accessed October 22, 2016. http://www.nytimes.com/ 2011/12/31/world/middleeast/rafe-al-essawi-a-moderate-in-an-increasingly-polarizediraq.html.

IISS. “Iraq: Maliki Power Grab Risks Fresh Civil War.” IISS Strategic Comments 18, no. 3 (2012): 1-3.

Jones, Sam and Borzou Daragahi. "Iraq's security forces ill-equipped to face militants." Financial Times, July 10, 2014. Accessed September 28, 2016. https://www.ft.com/content /a089e41e-081c-11e4-9afc-00144feab7de.

Kami, Aseel and Khalid al-Ansary. "Update 1 - Iraqi PM orders probe into state-run Trade Bank of Iraq." Reuters, June 2, 2011. Accessed September 24, 2016. http://www.reuters. com/article/iraq-bank-idUSLDE7511X320110602.

Katzman, Kenneth. "Iran's Influence in Iraq." In Surging out of Iraq?, edited by Steven J. Costel, 169-175. New York: Nova Science Publishers, 2008.

Katzman, Kenneth. "Iraq: Elections, Government and Constitution." Congressional Research Service. Accessed September 20, 2016. http://fpc.state.gov/documents/organization/ 76838.pdf.

Kelley, Matt. "Iraqi's resignation hurts fight against corruption." USA Today, September 9, 2007. Accessed October 22, 2016. http://usatoday30.usatoday.com/news/world/iraq/200709-09-iraqcorruption_N.htm.

Khedery, Ali. "Why we stuck with Maliki - and lost Iraq." Washington Post, July 3, 2014. Accessed November 7, 2016. https://www.washingtonpost.com/opinions/why-we-stuck-withmaliki--and-lost-iraq/2014/07/03/0dd6a8a4-f7ec-11e3-a606-946fd632f9f1_story.html. 
Kuoti, Yasir. "Exclusion and Violence in Post-2003 Iraq." Journal of International Affairs 69, no. 2 (Spring/Summer 2016): 19-28. Accessed September 19, 2016. EBSCOhost.

Lesperance, Wayne F. "The Rise of the Islamic State (IS).” In The New Islamic State: Ideology, Religion and Violent Extremism in the $21^{\text {st }}$ Century, edited by Jack Covarrubias, Tom Lansford and Robert J. Pauly, Jr., 15-28. New York: Ashgate Publishing, 2016.

McCoy, Terrence. "How the Islamic State evolved in an American prison." Washington Post, November 4, 2014. Accessed November 9, 2016. https://www.washingtonpost.com/news /morning-mix/wp/2014/11/04/how-an-american-prison-helped-ignite-the-islamic-state/.

Nance, Malcolm. Defeating ISIS. New York: Skyhorse Publishing, 2016.

Osman, Khalil F. Sectarianism in Iraq: The Making of State and Nation since 1920. New York: Routledge, 2015.

Page, Susan. "Panetta: '30-year war' and a leadership test for Obama." USA Today, October 6, 2014. Accessed November 11, 2016. http://www.usatoday.com/story/news/politics/2014 /10/06/leon-panetta-memoir-worthy-fights/16737615/.

Parker, Ned. "Machiavelli in Mesopotamia: Nouri al-Maliki Builds the Body Politic." World Policy Journal 26, no. 1 (Spring 2009): 17-25. Accessed August 16, 2016. Duke University Press Journals Online.

Parker, Ned and Caesar Ahmed. "Maliki seeks recount in Iraq elections." Los Angeles Times, March 22, 2010. Accessed September 20, 2016. http://articles.latimes.com/2010/mar /22/world/la-fg-iraq-election22-2010mar22.

Parker, Ned and Raheem Salman. "Notes from the Underground: The Rise of Nouri al-Maliki and the New Islamists." World Policy Journal 30, no. 1 (Spring 2013): 63-76. Accessed August 16, 2016. Duke University Press Journals Online.

Parker, Sam. "The New Nouri al-Maliki." Foreign Policy, July 21, 2009. Accessed September 7, 2016. http://foreignpolicy.com/2009/07/23/the-new-nuri-al-maliki/.

Peritz, Aki. "The Great Iraqi Jail Break.” Foreign Policy, June 26, 2014. Accessed October 28, 2016. http://foreignpolicy.com/2014/06/26/the-great-iraqi-jail-break/.

Petraeus, David. "Tonight on Charlie Rose." Interview by Charlie Rose. Frontline. PBS, September 28, 2016. https://charlierose.com/videos/28902.

Pollack, Kenneth M. "Iraq Back on the Brink: Maliki's Sectarian Crisis of His Own Making." Daily Beast, December 23, 2011. Accessed September 19, 2016. http://www.thedailybeast. com/articles/2011/12/23/iraq-back-on-the-brink-maliki-s-sectarian-crisis-of-his-ownmaking.html. 
Read, Russ. "Former SecDef Robert Gates Gives His Two Reasons Why ISIS Exists.” Daily Caller, June 29, 2016. Accessed November 11, 2016. http://dailycaller.com/2016/06/29/ former-secdef-robert-gates-gives-his-two-reasons-why-isis-exists/.

Rubin, Alissa J. "Ahmad Chalabi and the Legacy of De-Baathification in Iraq." New York Times, November 3, 2015. Accessed October 22, 2016. http://www.nytimes.com/2015/ 11/04/world/middleeast/ahmad-chalabi-and-the-legacy-of-de-baathification-in-iraq.html.

Rubin, Alissa J. "Blaming Politics, Iraqi Antigraft Official Vows to Quit." New York Times, September 7, 2007. Accessed October 22, 2016. http://www.nytimes.com/2007/09/07/ world/middleeast/07iraq.html.

Schwartzstein, Peter. "Welcome to Basrastan." Foreign Policy, July 1, 2015. Accessed October 29, 2016. http://foreignpolicy.com/2015/07/01/welcome-to-basrastan-iraq-basra-secessionoil-shiite-south/.

Sly, Liz. "In Iraq, a Sunni revolt raises specter of new war." Washington Post, January 6, 2014. Accessed October 12, 2016. https://www.washingtonpost.com/world/middle_east/in-iraq-asunni-revolt-raises-specter-of-new-war/2014/01/06/280f9216-7714-11e3-b1c5739e63e9c9a7_print.html.

Sullivan, Marisa. "Maliki's Authoritarian Regime." Middle East Security Report 10 (April 2013): 6-37. Accessed September 23, 2016. http://understandingwar.org/sites/ default/files/Malikis-Authoritarian-Regime-Web.pdf.

Tisdall, Simon. "WikiLeaks Cables: Saudi Arabia rated a bigger threat to Iraqi stability than Iran.” Guardian, December 5, 2010. Accessed November 8, 2016. https://www.theguardian. com/world/2010/dec/05/wikileaks-cables-saudi-meddling-iraq.

Visser, Reidar. A Responsible End? The United States and the Iraqi Transition, 2005-2010. Charlottesville, VA: Just World Publishing, 2010.

Visser, Reidar. "An Unstable, Divided Land." New York Times, December 15, 2011. Accessed November 7, 2016. http://www.nytimes.com/2011/12/16/opinion/an-unstable-dividedland.html?_r=1.

Visser, Reidar. "What Went Wrong in Iraq: The Khedery Version." Iraq and Gulf Analysis, July 6, 2014. Accessed November 7, 2016. https://gulfanalysis.wordpress.com/2014/07/.

Wilbanks, Mark and Efraim Karsh. "How the 'Sons of Iraq' Stabilized Iraq." Middle East Quarterly 17, no. 4 (Fall 2010): 57-70. Accessed September 12, 2016. EBSCOhost.

Wing, Joel. "More on Why Iraq's Anti-Corruption Chairman Quit." Musings on Iraq Blog, October 7, 2011. Accessed October 22, 2016. http://musingsoniraq.blogspot.com/ 2011/10/more-on-why-iraqs-anti-corruption.html. 
Yaphe, Judith S. "Maliki's maneuvering in Iraq." Foreign Policy, June 6, 2012, accessed September 20, 2016. http://foreignpolicy.com/2012/06/06/malikis-manuevering-in-iraq/. 